\title{
Catalysis in the Primordial World
}

\author{
N. Raos ${ }^{a^{*}}$ and V. Bermanec ${ }^{b}$ \\ a Institute for Medical Research and Occupational Health, Ksaverska c. 2, 10000 Zagreb, Croatia \\ ${ }^{b}$ Faculty of Science, Department of Geology, Horvatovac 102a, 10000 Zagreb, Croatia
}

This work is licensed under a Creative Commons Attribution 4.0

\begin{abstract}
\| Abstract
Catalysis provides orderly prebiotic synthesis and eventually its evolution into autocatalytic (self-reproduction) systems. Research on homogeneous catalysis is concerned mostly with random peptide synthesis and the chances to produce catalytic peptide oligomers. Synthesis of ribose via formose reaction was found to be catalysed by $\mathrm{B}(\mathrm{OH})_{4}^{-}$, presumably released by weathering of borate minerals. Oxide and clay mineral surfaces provide catalytic sites for the synthesis of oligopeptides and oligonucleotides. Chemoautotrophic or iron-sulphur-world theory assumes that the first (pioneer) organisms developed by catalytic processes on (Fe/Ni)S particles formed near/close hydrothermal vents. The review provides an overlay of possible catalytic reactions in prebiotic environment, discussing their selectivity (regioselectivity, stereoselectivity) as well as geological availability of catalytic minerals and geochemical conditions enabling catalytic reactions on early Earth.
\end{abstract}

\section{\| Keywords}

Chemoautotrophic theory, formose reaction, origin of life, prebiotic chemistry, random synthesis of biopolymers

\section{Introduction}

The "historical" 1953 Urey-Miller experiment"-3 may be misleading. The very idea of the emergence of life on Earth by organic synthesis could be traced back to Darwin's "warm little pond", expressed in a letter to Hooker, dated February 1, 1871, 4,5 and Oparin ${ }^{6}$ referred to many ways to obtain organic matter in prebiotic conditions. After all, as Max Bernstein pointed out, "the spark discharge method of making organic molecules is not as important as it was originally thought to be". ${ }^{7}$ Nearly two hundred organic compounds were found in interstellar clouds 8,9 and many more in meteorites (carbonaceous chondrites). There are literally millions of different organic compounds in the Murchison meteorite alone, of which 683 were positively identified. ${ }^{10}$ Chyba and Sagan estimated an input $10^{7}-10^{9} \mathrm{~kg} \mathrm{yr}^{-1}$ of organic material from cometary and asteroidal interplanetary dust particles (IDPs) on early Earth. ${ }^{11}$

The next problem with the Urey-Miller experiment is that primordial Earth's atmosphere was not Jupiter-like, composed of hydrogen, methane, ammonia and water vapour, as Urey proposed. ${ }^{12}$ According to new insights ${ }^{13,14}$ it was very much Mars-like, containing mostly carbon dioxide but with traces of volcanic gases (hydrogen, water vapour, hydrogen sulphide, sulphur dioxide and carbon monoxide). Simple molecules $\left(\mathrm{H}_{2} \mathrm{O}, \mathrm{CO}, \mathrm{NH}_{3}, \mathrm{CH}_{4}\right)$ along with complex ones were available on Earth from the early stages of its formation, but it seems that Earth's collision with a Mars-sized body, about 4.5 billion years ago which formed the Moon, removed its pristine atmosphere. ${ }^{15}$ This kind of

* Corresponding author: Nenad Raos, PhD

e-mail address: raos@imi.hr atmosphere did not easily yield amino acids after being exposed to ionizing agents, like UV radiation or electrical sparkling; ${ }^{16}$ however the synthesis could have been much improved by buffering reaction solution $\left(\mathrm{CaCO}_{3}\right)$ and lowering of its oxidation potential $\left(\mathrm{Fe}^{2+}\right) .{ }^{17}$ For the prebiotic synthesis and eventually emergence of life, it was also necessary to provide suitable geological habitat (increased concentration, temperature or pressure etc.) in the small environment we call Earth. ${ }^{18}$ In this respect, the development of the atmosphere and hydrosphere on Earth and also its stratification (formation of core, mantle and crust) was essential, which resulted in the production of the magnetic field around the planet that protects it from dangerous radiation from outer space. ${ }^{19}$

We should also bear in mind that prebiotic synthesis of biologically important compounds (amino acids, sugars, nucleobases, etc.) is not per se crucial for the emergence of life. It is also necessary to study the primordial organization of matter in self-sustainable and reproductive systems (pioneer organisms and protocells). However, to propose such systems, the persistence principle ${ }^{20}$ firstly needs to be put into effect, i.e. make a plausible hypothesis of the mechanisms for the concentration of primordial matter and its orderly (persistent) transformation. In other words, it is necessary to propose a suitable catalysis or catalytic system in the primordial world to be developed into a "primal dynamic steady-state replicative system", i.e. protolife, as it is defined thermodynamically. ${ }^{20}$ The obvious fact that the first catalysts were fuzzy and unspecific turned into their advantage because - as theoretical analysis of the development of autocatalytic systems shows - only random novel molecular species enable Darwinian evolution. ${ }^{21}$ 


\section{Oparin's solution: Homogeneous catalysis in coacervate droplets}

There are four basic requirements every plausible theory of the origin of life has to fulfil. It has to provide (i) a source of energy to drive molecular and macromolecular synthesis, (ii) a mechanism for the localized concentration of reactants to favour the required chemical reactions, (iii) suitable catalysis, and (iv) a suitable geochemical environment for these reactions and their products. Oparin's theory, 6,22 the first modern and complete theory of life origin, fulfils these requirements, but assuming geochemical environment and chemical processes that in the first half of the $20^{\text {th }}$ century seemed much likely to have occurred than they seem now. ${ }^{23}$ Oparin, namely, assumed (i) that the source of energy was provided by organic compounds dispersed in the primordial ocean, (ii) that they were concentrated by forming coacervate droplets, (iii) that catalysis was provided by protein or protein-like molecules, and (iv) that the ocean as a whole provided a suitable geochemical environment for the origin and development of life.

This theory was quite in line with the current biochemical doctrine of biocolloidy that regarded life as a colloidal phenomenon based on proteins. ${ }^{24}$ Thus, the essence of Oparin's theory is to explain how life as "a form of existence of protein bodies" (p. 136) ${ }^{6}$ emerged on Earth; however, this obsolete concept has been revived by the new concept of protoplasmic continuity and the models of organic films and microspheres. ${ }^{25}$

Catalysed reactions inside coacervate droplets provided their stability and thus "only the dynamically most stable colloidal systems secured for themselves the possibility of continued existence and evolution" (p. 191). ${ }^{6}$ Further evolution of coacervate droplets was enabled by linking of catalytic, i.e., enzymatic reactions. Evolution pressure has been a gradual depletion of substrates from the environment. This means that the initial catalysed reaction $\mathrm{A} \rightarrow \mathrm{B}$ gradually evolved into $\mathrm{C} \rightarrow \mathrm{A} \rightarrow \mathrm{B}, \mathrm{D} \rightarrow \mathrm{C} \rightarrow \mathrm{A} \rightarrow \mathrm{B}$, etc.

There are two critical flaws in Oparin's theory. The first is the regulation of protoenzymatic reactions in his droplets, and the second is the abiotic synthesis of enzymes, i.e., proteinoid homogeneous catalysts. Oparin never solved the first problem; he succeeded in preparing coacervate droplets with enzymes (which, due to accumulation of products, even divided themselves), but never with more than one enzyme. ${ }^{26}$ Lately, much more elaborate enzymatic systems have been devised; those based on phospholipid vesicles were even able to synthesize proteins and nucleic acids, ${ }^{27,28}$ but the problem of regulation persisted. The second problem, the evolution of catalysis inside the droplets, has two aspects: (1) catalysis of protein synthesis, and (2) abiotic generation of catalytic peptides.

Catalysts for protein synthesis may be such simple substances as sodium and potassium ions, which were abundant in the primordial ocean. It was namely demonstrated that in $1 \mathrm{M}$ concentration, they catalyse polymerization of glutamic acid with 1,1'-carbonyldiimidazole into 9- $\left(\mathrm{Na}^{+}\right)$ and 11-mer $\left(\mathrm{K}^{+}\right)$oligopeptides. ${ }^{29}$ More important, however, is that simple dipeptides Ser-His and Gly-Gly (less efficiently) catalyse polymerization of amino-acid esters, peptide fragments, and building blocks of peptide nucleic acids (PNA)..$^{30}$ Basic peptides, polymers of lysine, catalyse hydrolysis of phosphodiester bond, especially if their conformation is $\beta$-sheet rather than random coil. ${ }^{31}$

The second problem, abiotic generation of catalytic proteins, could possibly be solved by directed peptide synthesis. $^{32,33}$ Firstly, two small families (A and B) of four decapeptides each were synthesized, and by their combinations (A-B), 16 oligopeptides of length 20 were prepared. However, only four of them were soluble in water. By further combination, only one soluble oligopeptide of length 40 was obtained. This scheme could possibly explain the synthesis of long-chain peptides in the prebiotic environment, but it seems quite implausible, as P. G. Higgs pointed out, that selection of physical properties (i.e. water solubility) alone could generate many identical copies..$^{33}$ There are, namely, $20^{L}$ random sequences for 20 -oligopeptides, $L$ being the number of amino acids, and there is an enormous number of possible water-soluble peptides synthesized in this way to lead evolution to an autocatalytic mechanism.

In line with this research is the [GADV]-protein world hypothesis, ${ }^{34}$ stating that the first biological molecules were proteins composed of only four amino acids: glycine (G), alanine (A), aspartic acid (D), and valine (V). In the repeated heat-drying experiments (mimicking processes on primitive Earth) of aqueous solutions of the respective amino acids in equimolar concentrations, a library of random peptides were synthesized, which showed catalytic abilities to hydrolyze $\beta$-galactoside and amide (peptide) bond. . $^{35,36}$ The same was achieved by random [GADV]-octapeptides on BSA substrate. ${ }^{37}$ Random synthesis of [GADV]-peptides by microwave heating produced a library of 1-4 kDa peptides, ${ }^{38}$ which showed hydrolase- and oxidoreductase-like catalytic activities. ${ }^{39}$ Against all odds of combinatorics, it is clear that catalytic peptides could have been easily formed on primordial Earth.

\section{Prebiotic synthesis by homogeneous catalysis}

Despite the fact that the scheme for the prebiotic synthesis of sugars (formose reaction) has been known since the $19^{\text {th }}$ century, ${ }^{40}$ its catalysis by borates is a very new development. ${ }^{41}$ It was found that in the uncatalysed reaction, the yield of pentoses was only $30 \%$ (1\% ribose), less than the yield of hexoses $(55 \%)$, but more than that of tetroses $(10 \%)$ and higher sugars $\left(5 \%>\mathrm{C}_{6}\right)$. $^{42}$ Moreover, "formose" is not stable, but inclined to "browning" (asphalt problem) ${ }^{43}$ yielding insoluble organic matter (IOM) besides amino acids (when ammonia was added) and other low-molecular compounds by simulated synthesis on carbonaceous chondrites and comets. ${ }^{44,45}$ However, addition of borate in the form of artificially prepared mineral colemanite, $\mathrm{Ca}_{2} \mathrm{~B}_{6} \mathrm{O}_{11} \cdot 5 \mathrm{H}_{2} \mathrm{O}$, stabilizes formose solutions for months. ${ }^{46}$ The effect of borate was attributed mostly to the stabilization of pentoses, and to a lesser extent, of glyceraldehyde, the key autocatalytic reactant, keeping it in the enolate form (Fig. 1). Both substances form bis-complexes with borate anion, $\mathrm{B}(\mathrm{OH})_{4}{ }^{-}, \mathrm{B}(\mathrm{OH})_{3}+\mathrm{OH}^{-} \rightarrow \mathrm{B}(\mathrm{OH})_{4}{ }^{-}$ $(\mathrm{pK}=9.1)$ in basic solutions, as do many other geminal 

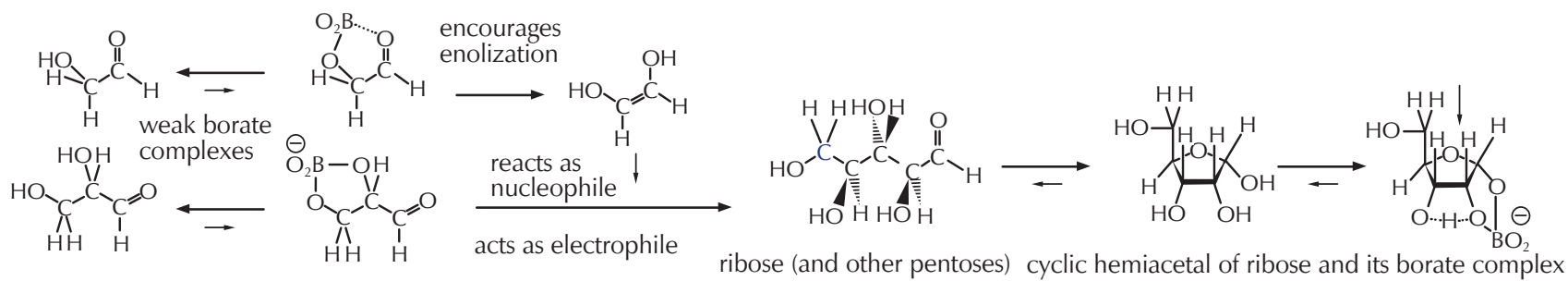

Fig. 1 - Formose reaction catalysed by borates: $\mathrm{B}(\mathrm{OH})_{4}{ }^{-}$stabilizes reactants (glycolaldehyde, glyceraldehyde) and the product (ribose); adapted after Ref. 43.

Slika 1 - Reakcija formoze katalizirana boratima: $\mathrm{B}(\mathrm{OH})_{4}^{-}$stabilizira reaktante (glikolaldehid, gliceraldehid) i produkt (ribozu), preuzeto iz ref. 43.

diols. ${ }^{47}$ Systematic study of the stability of pentose complexes with borate (borax) in concentration of $0-80 \mathrm{mM}$ revealed that ribose is the most stable pentose (others are xylose, lyxose and arabinose) in $80 \mathrm{mM}$ borate, but the least stable in the $0 \mathrm{mM}$ solution. ${ }^{48}$ It was also found that boric acid increases the thermostability of monosaccharides under acidic (ribose) and basic conditions (glucose). ${ }^{49}$ Analogous catalytic activity was found for silicate ions (sodium silicate), ${ }^{50}$ but its relevance for prebiotic synthesis is dubious. ${ }^{51,52}$

However, the question is whether boron-catalysed synthesis is possible in a prebiotic environment. Boron is among the rarest elements in the Universe (amount fraction $1 \mathrm{ppb}$ ) because it was neither synthesized by nucleosynthesis within stars nor during the Big Bang, but by nuclear fusion in cosmic-ray collisions. ${ }^{53,54}$ The catalytic role of boric acid is pointed out in discussions of possible reactions in seawater. ${ }^{55}$ The borate concentration in today's seawater is only $4.45 \mathrm{ppm},{ }^{56}$ but the finding of tourmaline in 3.8-billion-year-old rocks ${ }^{57}$ and boron minerals in carbonaceous chondrites ${ }^{58}$ speaks in favour of moderate borate concentrations in the waters of early Earth. Their abundance has to date increased following evolution of geological environments. ${ }^{18,59-61}$

However, the occurrence of its soluble minerals (evaporites, e.g. colemanite) demands a developed and rare environment like basic lakes, or boron-rich lakes. Benner et al. ${ }^{43}$ envisaged such a geochemical environment in subaerial intermountain desert valleys with borate-rich aquifers $(\mathrm{pH}=10-11)$, which collect runoff from a watershed containing serpentinizing olivines and igneous tourmallines, being also rich in formaldehyde, formamide, ammonium formate, and similar chemicals. Due to $\mathrm{CO}_{2}$ apsorption, the $\mathrm{pH}$ of aquifiers dropped to 6 , which enabled further prebiotic synthesis and prevented formation of macromolecular material (asphalt).

Boric ions also catalyse amino acid polymerization. ${ }^{55}$ This kind of catalytic activity was also found for sodium and potassium ions, ${ }^{29}$ but the systematic study of the influence of $\mathrm{pH}$, temperature, and metal concentration on the polymerization of glycine revealed a negative influence of other divalent metals. ${ }^{62}$ Namely, metal ions, which easily form complexes with glycine and its oligomers $\left(\mathrm{Cu}^{2+}, \mathrm{Ni}^{2+}\right.$, $\left.\mathrm{Pb}^{2+}, \mathrm{Cd}^{2+}, \mathrm{CO}^{2+}, \mathrm{Hg}^{2+}\right)$, inhibit Gly polymerization in contrast to $\mathrm{Fe}^{2+}$ and $\mathrm{Mg}^{2+}$, which have virtually no influence.
That led to the conclusion that these metals were immobilized in the form of respective sulphides, supporting this way the chemoautrophic (or "iron-sulphur-world") theory of life origin (see the fifth paragraph). Metallic cations like $\mathrm{UO}^{2-}, 63,64 \mathrm{~Pb}^{2+}, \mathrm{Zn}^{2+}$ and those of lanthanides ${ }^{65,66}$ catalyse nucleotide polymerization, and even non-enzymatic template directed synthesis of RNA oligomers. ${ }^{67,68}$ However, because of the scarcity of these ions in modern as well as in early Earth's geological habitat, their role in prebiotic synthesis could hardly be important.

\section{Heterogeneous catalysis: Synthesis on clay minerals}

The hypothesis that clays played a decisive role in the origin of life, expressed originally by J. D. Bernal in $1949^{69}$ and later elaborated by C. Ponnamperuma, ${ }^{70}$ is still very popular (Table 1). Clays were easily found on early Earth because they are produced by weathering of silicate rocks through different processes involving liquid water and vapours. Montmorillonite, the most interesting clay mineral in the context of the origin of life, is formed by weathering of volcanic ash, and the first occurrence of kaolin in geological environment is connected to the activation of hydrothermal alteration of feldspar-containing rocks.

Except on Earth, clay minerals were found on Mars, ${ }^{71,72}$ in meteorites, especially liquid-water-altered Cl1 carbonaceous chondrites, ${ }^{73,74}$ as well as on asteroids. ${ }^{75}$ It was hypothesized that clay minerals are present on comets, making them allegedly places for prebiotic synthesis and even for the origin of life (interstellar panspermia). ${ }^{76}$ Clay minerals are characterized by very small particles or crystals that increase the active surface of the particles, and make clay mineral more efficient in processes of adsorption and exchanging ions. They have layered structures, sometimes expandable (like in smectite group minerals), with enough space between the layers to accommodate ions, and even organic molecules making them catalysts in organic synthesis. ${ }^{77,78}$ Therefore, clay deposits, in combination with plate tectonics, might play an important role in the production and concentration of prebiotic organic molecules crucial for the emergence of life.

As J.-F. Lambert pointed out, clay and similar minerals (silicates, $\mathrm{SiO}_{2}, \mathrm{Al}_{2} \mathrm{O}_{3}, \mathrm{TiO}_{2}$ ) are not, strictly speaking, catalysts 
Table 1 - Prebiotic reactions catalysed by clay minerals

Tablica 1 - Predbiološke reakcije katalizirane mineralima gline

\begin{tabular}{|c|c|c|}
\hline $\begin{array}{l}\text { Reaction } \\
\text { Reakcija }\end{array}$ & $\begin{array}{l}\text { Catalyst } \\
\text { Katalizator }\end{array}$ & $\begin{array}{l}\text { References } \\
\text { Referencije }\end{array}$ \\
\hline formose reaction & kaolinite, illite & 173,174 \\
\hline polymerization of Gly & kaolinite, bentonite & 175 \\
\hline polymerization of Gly & kaolinite & 176 \\
\hline polymerization of Gly & $\begin{array}{l}\text { phyllosilicates (kaolinite } \\
\text { montmorillonites, nontronites) }\end{array}$ & 177 \\
\hline polymerization of Gla, Ala & mono-ionic bentonites & 88 \\
\hline polymerization of Gly and Gly ${ }_{2}$ & $\mathrm{Ca}^{2+}$ - and $\mathrm{Cu}^{2+}$-montmorillonite & 178 \\
\hline polymerization of negatively charged amino acids (Glu, Asp, O-phospho-Ser) & illite & 179,180 \\
\hline polymerization of pyroGlu & kaolinite, montmorillonite & 181 \\
\hline polymerization of Gly, Ala, (Ala+Gly), (Ala+Gly $)$, (Ala+DKP) & montmorillonite, hectorite & 87 \\
\hline polymerization of Gly, Tyr, (Gly+Tyr) & $\mathrm{Cu}^{2+}$-hectorite, montmorillonite & 182 \\
\hline $\begin{array}{l}\text { polymerization of Gly, Ala, (Ala+Gly), Pro, (Pro+Gly), (Pro+Gly })_{2},(\text { Pro+Ala), Val, } \\
(\text { Val+Gly), (Val+Gly }) \text {, (Val+Ala), Leu, (Leu+Gly), (Leu+Gly }) \text {, (Leu+Ala) }\end{array}$ & hectorite & 97 \\
\hline polymerization of AMP with EDAC & $\mathrm{Na}^{+}$-montmorillonite & 183 \\
\hline polymerization of ImpU & montmorillonite & 184,185 \\
\hline polymerization of ImpC & montmorillonite & 186 \\
\hline polymerization of ImpA & montmorillonite & 179,187 \\
\hline polymerization of ImpA & $\mathrm{Na}^{+}$-montmorillonite & 122 \\
\hline polymerization of ImpA, ImpU & montmorillonite & 115 \\
\hline polymerization of ImpA + ImpC & montmorillonite & 112,187 \\
\hline polymerization of MeadpA, MeadpU & montmorillonite & 188,189 \\
\hline $\begin{array}{l}\text { polymerization of } I m p X+X m P \\
(X=A, C, G, U, I m)\end{array}$ & montmorillonite & 190 \\
\hline $\begin{array}{l}\text { polymerization of ImpA, ImpU, } \\
\text { ImpA + ImpU }\end{array}$ & $\mathrm{Na}^{+}$-montmorillonite & $\begin{array}{l}116,117, \\
191\end{array}$ \\
\hline polymerization of $\operatorname{Imp}(\mathrm{A}, \mathrm{C}, \mathrm{U}, \mathrm{G})$ & montmorillonite & 119,120 \\
\hline
\end{tabular}

(pseudo-enzymes) in peptide synthesis since the polymerization of amino acids is an endergonic process. ${ }^{79}$ The function of clays in prebiotic synthesis was to concentrate reactants on mineral surfaces enabling thermal polymerization by the drying/wetting process. The adsorption of amino acids on mineral surfaces was not yet sufficiently explained, but three possible mechanisms were proposed (Fig. 2). The first was the "formation of an anhydride" with surface hydroxyl groups; that is, formation of $\mathrm{Si}-\mathrm{O}-\mathrm{CO}-\mathrm{R}$ moieties on the surface of silicate minerals. ${ }^{80}$ The second mechanism was the formation of complexes with $\mathrm{Ti}^{4+}\left(\mathrm{TiO}_{2}\right)^{81}$ or $\mathrm{Al}^{3+}$ and $\mathrm{Cu}^{2+} .82$ The third proposed mechanism was the formation of hydrogen bonds between $-\mathrm{COOH}$ groups of amino acids and $\mathrm{Si}-\mathrm{OH}$ groups of silicate mineral. ${ }^{83,84}$ The study of the glycine intercalation into kaolinite silicate layer found the drop of activation energy by heating, from $21 \mathrm{~kJ} \mathrm{~mol}^{-1}\left(20-65{ }^{\circ} \mathrm{C}\right)$ to $5.8 \mathrm{~kJ} \mathrm{~mol}^{-1}\left(65-80{ }^{\circ} \mathrm{C}\right) .85$

Adsorption of an amino acid depends on its chemical form. Amino acids, as neutral molecules $\left(\mathrm{H}_{2} \mathrm{~N}-\mathrm{CHR}-\right.$ $\mathrm{COOH}$ ) dominate in the adsorption from gas phase on dried surfaces, whereas they are adsorbed better as zwitterions $\left({ }^{+} \mathrm{H}_{3} \mathrm{~N}-\mathrm{CHR}-\mathrm{COO}^{-}\right)$from aqueous solutions. In ad- dition, with charged groups in side chains, they are better adsorbed than those with uncharged side chains. ${ }^{86}$ That finding, however, speaks against the theory of prebiotic synthesis on clay minerals, because amino acids with neutral side chains prevail in proteins. It also contradicts the [GADV]-theory, because it includes three amino acids, out of four, with neutral side chains (G, A, V).

The second problem with the clay theory is a very low yield of polymers. Performing the drying/wetting cycles $\left(80{ }^{\circ} \mathrm{C}\right)$ on montmorillonite and hectorite, yields far below $1 \%$ were obtained for glycine and alanine ${ }^{87}$, and $<2 \%$ alanine had converted to dialanine after 56 days of drying/ heating/wetting cycles $\left(45 / 94{ }^{\circ} \mathrm{C}\right)$ on mono-ionic bentonites. ${ }^{88}$ Obviously, a higher temperature gives a better yield, but the decomposition of adsorbed material takes place at about $200{ }^{\circ} \mathrm{C} .{ }^{89}$

It was hypothesized that clay minerals had been the key chiral agents for the preference of L-amino acids in proteins. The hypothesis has been strongly supported by the finding that heating of aspartic acid on kaolin at $90{ }^{\circ} \mathrm{C}$ yielded $25 \%$ polymerization of L- but only $3 \%$ of D-iso- 

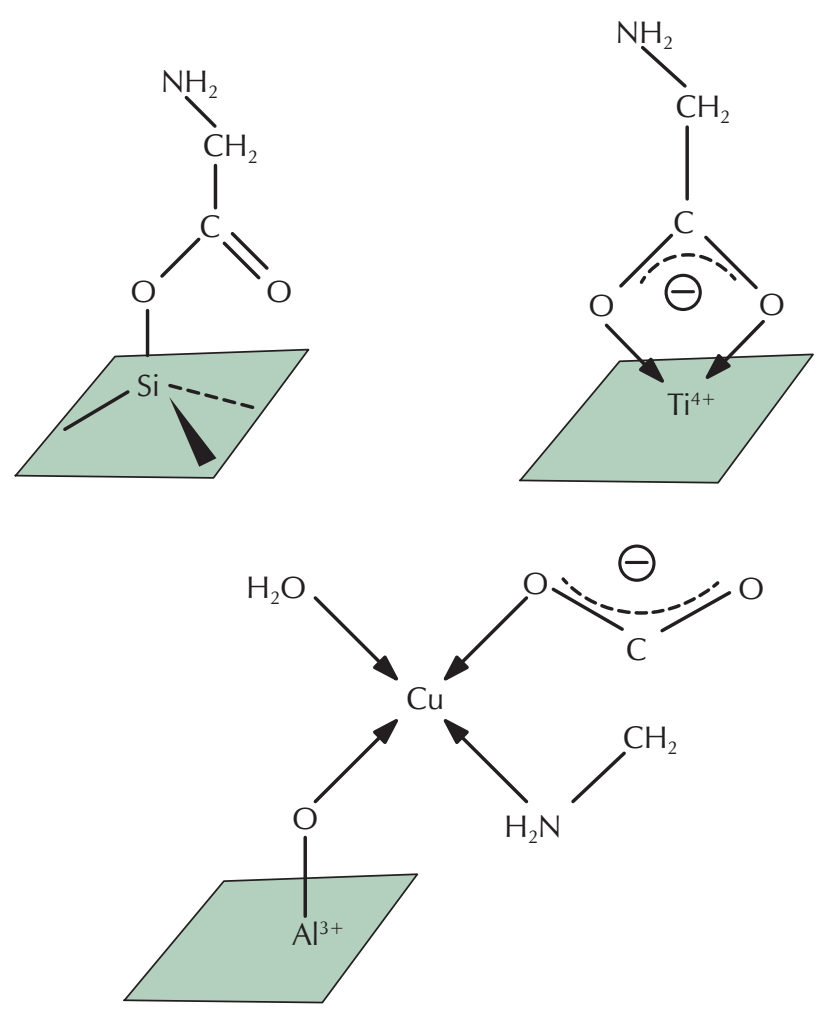

Fig. 2 - Proposed mechanisms for amino-acid adsorption on mineral surfaces; formation of an anhydride with surface hydroxyl groups, formation of complexes with $\mathrm{Ti}^{4+}$ or with $\mathrm{Al}^{3+}$ and $\mathrm{Cu}^{2+}$

Slika 2 - Pretpostavljeni mehanizmi za adsorpciju aminokiselina na površine minerala: stvaranje anhidrida s hidroksilnim skupinama na površini te nastajanje kompleksa s $\mathrm{Ti}^{4+}$ ili $\mathrm{s} \mathrm{Al}^{3+} \mathrm{iCu}^{2+}$

mer. ${ }^{90}$ However, the problem is far from simple. In 1971, better adsorption of L- than D-phenylalanine on kaolin was found, ${ }^{91}$ but this has not been confirmed..$^{92}$ L-glutamic acid is better adsorbed on $\mathrm{Na}^{+}$-montmorillonite $(\mathrm{pH}=6.0)$ than its D-isomer, but quite opposite holds for aspartic acid, and both amino acids proved more reactive to deamination in their L-forms. ${ }^{93}$ The problem is complex not only because of the different mechanisms of adsorption and polymerization of different amino acids, but also because different enantioselectivity could be observed even on different crystal faces of the same mineral. ${ }^{94} \mathrm{At}$ any rate, enantioselective adsorption and polymerization of amino acids on mineral surfaces cannot be denied, and it was even explained by "occasional chirality" of clay crystal lattice ${ }^{70}$ or by stacking of the optically active ions in the interlayer space, ${ }^{95,96}$ but the connection with biological homochirality remains obscure.

Research on other non-clay minerals revealed that the most efficient catalyst for amino acid polymerization is alumina, showing a yield of even $13.06 \%$ for glycine dimerization, ${ }^{97}$ which is not at all surprising as alumina is a well-known industrial catalyst. In addition to silica, alumina is a very common product of weathering and hydrothermal alteration of silicate rocks. A systematic study of the polymerization of glycine on mineral surfaces showed the order of catalytic efficiency: rutile $>$ anatase $>\gamma$-alu- mina $>$ forsterite $>\alpha$-alumina $>$ magnetite $>$ hematite $>$ quartz $>$ amorphous silica. ${ }^{98}$ Martra and coworkers prepared poly-Gly up to 16 units long by condensation of the amino acid vapour $\left(130{ }^{\circ} \mathrm{C}\right)$ on $\mathrm{TiO}_{2}$ (anatase) and amorphous $\mathrm{SiO}_{2}$ surfaces. ${ }^{99}$ That line of research ${ }^{100}$ opens a number of possibilities for prebiotic synthesis, but it has to be taken into consideration that there is a quite significant difference in polymerization efficiency for different amino acids on different minerals, e.g. $0.07-13.06 \%$ for dimerization on alumina. ${ }^{97}$ Also, many of the studied minerals were, and still are, rare. Forsterite, $\mathrm{Mg}_{2} \mathrm{SiO}_{4}$, was the most abundant; magnetite, rutile and anatase were not so plentiful, because they are accessory minerals. Amorphous silica was also present, but as a new, weathering and alteration product.

The problem of nucleic acid synthesis on clay minerals ${ }^{101,102}$ has gained importance since RNA-world hypothesis came to the fore. This hypothesis ${ }^{103-105}$ implies that RNAs were molecules on which all original biological functions of proto-organisms were based; from them developed both DNA and proteins. Such a hypothesis put many requirements on the theory of prebiotic synthesis. In contrast to proteins, which were presumably synthesized by polymerization of amino acids, which were in turn produced by simple Miller-like synthesis, prebiotic synthesis of RNA monomers is much more complex both chemically ${ }^{106-108}$ and geochemically. ${ }^{109-111}$ However, it has to be pointed out that experiments aimed at clay-catalysed synthesis seem much more convincing than those designed for the synthesis of peptides. Polymerization reactions were exergonic because they were performed by using condensing agents (EDAC) or activated nucleotides, mostly ImpA. The second reason is that only one mineral has been successfully employed, i.e. montmorillonite, one of the most abundant clay minerals on Earth as well as Mars. ${ }^{71}$

The third reason is that a much better degree of polymerization has been achieved with nucleotides than with amino acids, and even selectivity has been observed. In the experiment of copolymerization of $\operatorname{ImpA}$ and $\operatorname{ImpC}^{112} 8,10$, 5 and 4 isomers with 2,3,4, and 5 mers, respectively, were detected, obviously much less than the number of isomers predicted in random synthesis $(8,32,128$ and 512). By binding of decameric primer on $\mathrm{Na}^{+}$-montmorillonite, oligomers up to 50 monomer units were prepared. ${ }^{113}$ Enantioselectivity was also observed because D-D and L-L dimers were preferentially formed starting from racemic $(D, L)$ nucleotides. ${ }^{114}$ However, it holds true only for purine nucleotides (ImpA), which gave $66.9 \%$ homochiral dimers in contrast to $39.2 \%$ homochiral dimers for ImpU; ${ }^{115}$ quaternary reactions $(\mathrm{ImpA}+\mathrm{ImpU})$ gave $63.5 \%$ homochiral dimers and $74.5 \%$ homochiral trimers. ${ }^{116}$ Similar results were obtained for tetramers and pentamers. ${ }^{117}$

Molecular modelling revealed that the decisive factor in enantioselectivity are dipole interactions between nucleotide anion and zwitterion (Fig. 3) on clay surface. ${ }^{115} \mathrm{Cou}-$ lombic interactions are also dominant for the montmorillonite catalytic activity. It was shown that montmorillonites with smaller surface layer charges are better catalysts. ${ }^{118-120}$ By studying the oligomerization reaction of ImpU and ImpA inhibited by $\mathrm{N}^{6}, \mathrm{~N}^{6}$-dimethyladenine and $\mathrm{d} \mathrm{A}^{5}$ ppdA on montmorillonite, it was found that activated RNA mon- 
omers (ImpU and ImpA) bind only to the silicate surface of the clay interlayer, on catalytic sites about $1.5 \mathrm{~nm}$ apart $\left(1-2 \cdot 10^{14}\right.$ sites per milligram). ${ }^{121}$ On clay surfaces, purine nucleotides bind more strongly and are oriented differently than those of pyrimidine. This may account for the observed regioselectivity $\left(3^{\prime}, 5^{\prime}\right.$ vs. $2^{\prime}, 5^{\prime}$ links), but the exact mechanism of selective binding and polymerization is not yet known.

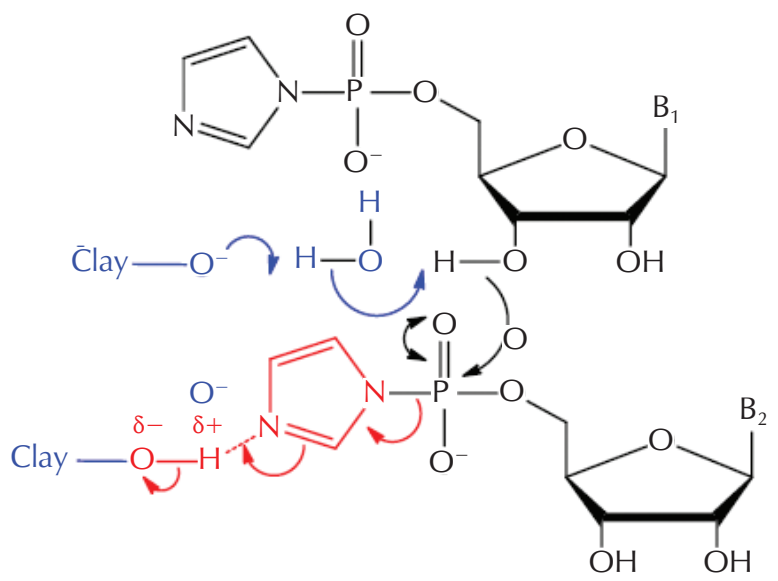

Fig. 3 - Mechanism of polymerization of nucleotides on clay surfaces (adapted from Ref. 115)

Slika 3 - Mehanizam polimerizacije nukleotida na površinama glina (preuzeto iz ref. 115)

The catalytic properties of montmorillonite depend also on the background electrolyte, i.e., on its salt form. Catalytic activity is higher for smaller ions $\left(\mathrm{Li}^{+}>\mathrm{Na}^{+}>\mathrm{K}^{+}>\mathrm{Rb}^{+}>\right.$ $\left.\mathrm{Cs}^{+}, \mathrm{Mg}^{2+}>\mathrm{Ca}^{2+}>\mathrm{Sr}^{2+}>\mathrm{Ba}^{2+}\right) .{ }^{120}$ The best catalytic activity for $\mathrm{Na}^{+}$-montmorillonite was observed in $1 \mathrm{M} \mathrm{NaCl}$ solution, ${ }^{122}$ close to salt concentration $(c=0.9-1.2 \mathrm{M})$ of the primordial ocean. ${ }^{123}$

\section{Reactions on sulphide surfaces}

Chemoautotrophic (or iron-sulphur-world) theory of life origin $^{124-127}$ rests on two assumptions. The first is that the first prebiotic catalytic reactions took place on $\mathrm{Fe} / \mathrm{Ni}$ sulphide particles evolving gradually to autocatalytic systems, and ultimately to the first (pioneer) organisms. The second assumption is that the driving power for all prebiotic processes has been the oxidative formation of pyrite, $\mathrm{FeS}_{2}$, by reaction of FeS with $\mathrm{H}_{2} \mathrm{~S} .{ }^{128}$ The hypothesis is supported by its correlation with iron-sulphur proteins, ${ }^{129}$ i.e., proteins with iron-sulphide and similar metal-sulphide catalytic centres, ${ }^{130-132}$ which constitute the group of phylogenetically oldest enzymes, e.g. nitrogenases. ${ }^{133}$ As early as 1974 , $R$. Osterberg hypothesized that the first electron carriers were in the form of $\mathrm{FeS} / \mathrm{FeS}_{2}$ particles. ${ }^{134}$

This theory is also concordant with the hypothesis that all life forms evolved from hyperthermophilic organisms, because the oldest extant life forms (e.g. Crenarchaeota, Nanoarchaeota) are chemoautotrophic hyperthermophiles. ${ }^{135}$
Hyperthermophiles ${ }^{136}$ were in turn found near the underwater hydrothermal vents at Midoceanic ridges rich in dissolved hydrogen sulfide, ${ }^{137,138}$ the possible geological habitat of pioneer organisms. ${ }^{126}$ (Other habitats might also be magnesium-rich komatiite lava deposits ${ }^{139}$ and hydrothermal systems developed as a consequence of asteroid impacts on early Earth, ${ }^{140}$ but in our opinion, such events were rare.) Hyperthermophiles had possibly evolved from pioneer organisms, and were later adapted to "milder" surface conditions. ${ }^{141,142^{*}}$

Catalytic particles were formed by reaction of hydrogen sulphide with metal ions $\left(\mathrm{Fe}^{2+}, \mathrm{Ni}^{2+}, \mathrm{W}^{4+}\right)$ dissolved in ocean water. They very probably formed protocell-like "monosulphide bubbles", 143,144 by "chemical-garden" (chemobrionics) reactions. ${ }^{145}$ This provided the first (inorganic) membranes, as well as catalytic surfaces (mineral substructure). Simple molecules from volcanic liquid water phase (CO, $\mathrm{CO}_{2}, \mathrm{COS}, \mathrm{NH}_{3}, \mathrm{H}_{2} \mathrm{~S}, \mathrm{~N}_{2}, \mathrm{H}_{2}, \mathrm{HCN}$ ) were adsorbed on a mineral substructure making an organic superstructure ${ }^{126}$ prone to all kinds of chemical transformations. This hypothesis is supported by the finding that iron and copper sulphide minerals (pyrrhotite, pyrite, covellite, bornite, chalcopyrite, tetrahedrite) proved to be efficient catalysts in converting formamide $\left(\mathrm{H}_{2} \mathrm{NCHO}\right)$ into purine, adenine, and other heterocyclic bases under simulated prebiotic conditions. ${ }^{146}$ It was also shown that pyrite and greigite $\left(\mathrm{Fe}_{3} \mathrm{~S}_{4}\right)$ catalyse $\mathrm{CO}_{2}$ reduction, converting it respectively into formate ${ }^{147}$ and methanol, formic, acetic and pyruvic acid. ${ }^{148} \mathrm{FeS}$ also appears to be a suitable agent for reducing nitrates and nitrites to ammonia under primordial acidic conditions. ${ }^{149}$

The basic idea of the iron-sulphur-world theory is that the electrons released by oxidation of iron(II) sulphide were used for reduction of simple molecules from liquid water phase and synthesis of complex organic compounds on (Fe,Ni)S surfaces. Many such reactions were proven experimentally, ${ }^{124,126}$ like reduction of nitrogen into ammonia at 1 bar, $80{ }^{\circ} \mathrm{C}$, and $\mathrm{pH}=3-4:^{150}$

$$
\mathrm{N}_{2}+3 \mathrm{FeS}+3 \mathrm{H}_{2} \mathrm{~S} \rightarrow 3 \mathrm{FeS}_{2}+2 \mathrm{NH}_{3}
$$

synthesis of methanethiol (along with other sulphur compounds, $\mathrm{CS}_{2}, \mathrm{Me}_{2} \mathrm{~S}, \mathrm{R}-\mathrm{SH}$ ) from carbon dioxide at 1 bar and $75{ }^{\circ} \mathrm{C}:{ }^{151}$

$$
\mathrm{CO}_{2}+3 \mathrm{FeS}+4 \mathrm{H}_{2} \mathrm{~S} \rightarrow \mathrm{CH}_{3} \mathrm{SH}+3 \mathrm{FeS}_{2}+2 \mathrm{H}_{2} \mathrm{O}
$$

and the synthesis of pyruvic acid from carbon monoxide at 2000 bar and $250{ }^{\circ} \mathrm{C}::^{152}$

$$
3 \mathrm{CO}+2 \mathrm{FeS}+2 \mathrm{H}_{2} \mathrm{~S} \rightarrow 2 \mathrm{FeS}_{2}+\mathrm{CH}_{3} \mathrm{COCOOH} \text {. }
$$

Other reactions, not directly involving the formation of pyrite, could also be catalysed by such a mineral substructure. Using FeS and/or $\mathrm{Fe}(\mathrm{OH})_{2}$ as a catalyst, ${ }^{153,154}$ amino acids (Ala, Glu, Phe, Tyr) were synthesized in the maxi-

\footnotetext{
* There is, however, an alternative explanation for the evolution from hyperthermophilic organisms, namely that these organisms were the only survivors after large asteroid impacts in early Earth's history, Ref. $129,171,172$.
} 
mum $35-58 \%$ yield from corresponding keto acids (1 bar, 75-100 $\left.{ }^{\circ} \mathrm{C}, \mathrm{pH}=9-11\right)$ :

$$
\begin{aligned}
& \mathrm{RCOCOOH}+2 \mathrm{Fe}^{2+}+\mathrm{NH}_{3}+2 \mathrm{H}^{+} \rightarrow \\
& \rightarrow \mathrm{RCH}\left(\mathrm{NH}_{2}\right) \mathrm{COOH}+2 \mathrm{Fe}^{3+}+\mathrm{H}_{2} \mathrm{O} .
\end{aligned}
$$

Even more complex schemes were devised, like oligopeptide and purine synthesis from carbon monoxide, ${ }^{155}$ and - quite speculative - anaerobic citric acid cycle on (Fe,Ni)S catalyst. ${ }^{156}$ The hypothesis of the evolution of bacterial (acetogens) and archaea (metanogens) metabolisms by carbon $\left(\mathrm{CO}_{2}\right)$ fixation on catalytic (Fe, Ni)S minerals in alkaline hydrothermal vents is also based on such a speculative scheme. ${ }^{157}$

Wächtershäuser also proposed a theory of evolution on the surface of $(\mathrm{Fe}, \mathrm{Ni}) \mathrm{S}$ catalyst ${ }^{126}$ from the assumption that some ligands may dramatically increase the activity of (metal) catalyst. ${ }^{158}$ This led to the development of autocatalytic systems, which in turn led to coevolution of proteins and nucleic acid synthesis by autocatalytic feedback. The theory also explains the formation of the first protocells, by the process of surface lipophilization and the establishment of $\mathrm{pH}$ gradient across membrane (chemiosmosis). The hypothesis is experimentally supported by studying vesicle formation in the presence of various minerals, e.g., pyrite and montmorillonite. ${ }^{159,160}$ However, experiments aimed at synthesis of amino acids and nucleic bases from $\mathrm{CO}_{2}$ using $\mathrm{FeS} / \mathrm{H}_{2} \mathrm{~S}$ system failed, ${ }^{161}$ and it was shown that sulphide minerals stimulate degradation of RNA by catalysing the hydrolysis of phosphodiester bonds. ${ }^{146}$

\section{Conclusion}

The troubles with the theories of life origin stem from the very nature of the scientific research: the problem of higher complexity has to be divided into a set of less complex ones. Thus, the riddle of the emergence of life on Earth should be solved by answering questions concerning the potential catalytic substances available on early Earth, composition of its primordial hydrosphere, lithosphere and atmosphere, efficiency of mineral catalysts in synthesizing biopolymers, evolution of autocatalytic systems, self-assembly of molecules in nanostructures, e.g. nanovesicles, ${ }^{162-164}$ evolution of the protocells and the first anaerobic metabolism ${ }^{165}$, and so forth. Despite much effort in solving these problems, it is not yet possible to comprise all the experimental data in a consistent theory; however, the general shape of the evolution leading to the first protoorganisms can be envisaged.

Evolution of organic matter is dependent on the evolution of inorganic matter; the diversification of minerals opened new possibilities for catalysed reactions, and consequently for greater diversity of prebiotic forms (Table 2). The origin of life, viewed as the result of the development of catalysis, is intimately connected with clays and sulphides, so the emergence of life as we know it, was impossible before these minerals had appeared, i.e. before Earth differentiation and plate tectonics. ${ }^{19}$ This opens a possibility that some kind of prebiotic forms existed before the conditions for the iron-sulphur world had been met, suggesting the gradual evolution from biopolymers into autocatalytic (metabolic) systems. At any rate, the emergence of life on Earth before $3.8 \mathrm{Ga}^{166}$ was not caused by long-term evolu-

Table 2 - Early history of Earth (adapted after Ref. 18)

\begin{tabular}{|c|c|c|c|c|}
\hline $\begin{array}{l}\text { Years from } \\
\text { present/Ga } \\
\text { Godina od } \\
\text { sadašnjosti / Ga }\end{array}$ & $\begin{array}{l}\text { Mineral species } \\
\text { Mineralne vrste }\end{array}$ & $\begin{array}{l}\text { Kinds of rocks and } \\
\text { minerals } \\
\text { Vrste stijena i minerala }\end{array}$ & $\begin{array}{l}\text { Examples } \\
\text { Primjeri }\end{array}$ & $\begin{array}{l}\text { Geological events and } \\
\text { possible prebiotic processes } \\
\text { Geološki događaji i } \\
\text { mogući predbiološki procesi }\end{array}$ \\
\hline$>4.56$ & 60 & $\begin{array}{l}\text { chondrules } \\
\text { pre-solar grains }\end{array}$ & $\begin{array}{l}\text { olivine } \\
\text { forsterite } \\
\text { troilite } \\
\text { magnetite }\end{array}$ & formation of the Solar System \\
\hline $4.56-4.55$ & 250 & $\begin{array}{l}\text { chondrites } \\
\text { achondrites } \\
\text { iron } \\
\text { clay minerals } \\
\text { carbonates }\end{array}$ & $\begin{array}{l}\text { smectites } \\
\text { feldspars } \\
\text { zeolites }\end{array}$ & $\begin{array}{l}\text { accretion and alternation of planetesimals } \\
\text { formation of Earth } \\
\text { Earth differentiation (core, mantle, crust) } \\
\text { clay-mineral catalysis }\end{array}$ \\
\hline $4.55-4.0$ & 350 & $\begin{array}{l}\text { igneous rocks } \\
\text { evaporites }\end{array}$ & $\begin{array}{l}\text { amphiboles } \\
\text { micas } \\
\text { halite }\end{array}$ & $\begin{array}{l}\text { plate tectonics } \\
\text { hydrothermal vents } \\
\text { Miller-like synthesis } \\
\text { evaporite catalysis } \\
\text { sulphide catalysis }\end{array}$ \\
\hline $4.0-3.2$ & 1000 & granitoids & quartz & the first life \\
\hline $3.2-2.8$ & 1500 & $\begin{array}{l}\text { granite } \\
\text { pegmatite } \\
\text { sulphates }\end{array}$ & $\begin{array}{l}\text { quartz } \\
\text { alkali feldspars }\end{array}$ & $\begin{array}{l}\text { development of } \\
\text { photoautotrophic and anaerobic } \\
\text { metabolism }\end{array}$ \\
\hline 2.5-1.9 & 4000 & & $\begin{array}{l}\text { secondary oxides } \\
\text { oxysalts } \\
\text { gypsum }\end{array}$ & $\begin{array}{l}\text { great oxidation } \\
\text { development of aerobic metabolism }\end{array}$ \\
\hline
\end{tabular}

Tablica 2 - Rana povijest Zemlje (sastavljeno prema ref. 18) 
tion of organic matter in the "primordial soup", as Oparin viewed it, but has been rather a natural consequence of geochemical evolution.

It is notorious that theories of the evolution of autocatalytic systems are not based on any real chemical system, much less on real geological habitats. Despite a huge number of works on polymerization of amino acids on clay and oxide minerals, it is still unclear how they would have been employed in prebiotic synthesis; this presumes them to be good catalysts for all protein amino acids, which obviously not the case. Most of the prebiotic reactions, such as amino acid synthesis, ${ }^{167}$ formose, and iron-sulphur-world reactions need basic conditions, but it is hard to imagine such reactions on early Earth with $\mathrm{CO}_{2}$-rich atmosphere and rainwater with $\mathrm{pH}=3.7$, and temperature of $70{ }^{\circ} \mathrm{C} .{ }^{13}$ It is, however, highly probable that many different catalyst systems were contemporarily active, because, as $S$. A. Kauffman put it, "the more complex web of coupled reactions, together with the chance that molecules in the web are catalysts for the same reactions, the easier it is to form collectively autocatalytic sets", i.e. protocells. ${ }^{168}$ This leads to an obvious conclusion that the development of a geological habitat, i.e., the rising number of mineral species, led to the emergence of life on Earth. ${ }^{169}$

The idea that it is possible to reconstruct Darwin's "warm little pond", i.e., that it should be possible to design an experiment from which some kind of proto-organism would emerge by mixing of chemicals, proved unsuccessful; $; 6,145,170$ it is naïve to expect to be able to reproduce processes that took place on thousands of square kilometres and lasted a few hundred million years by a test-tube experiment. However, from another point, it does not seem impossible to find mineral catalysts that would be capable of directing the key prebiotic reactions needed for the emergence of life on this planet.

\section{List of abbreviations and symbols \\ Popis kratica i simbola
Pist}

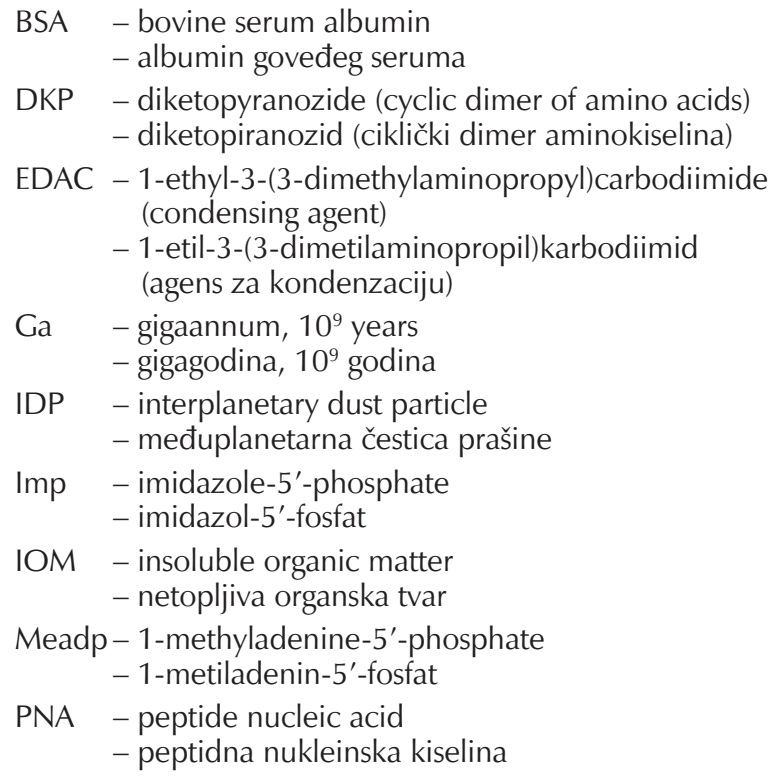

- peptidna nukleinska kiselina

\section{References Literatura}

1. S. L. Miller, A production of amino acids under possible primitive Earth conditions, Science 117 (1953) 528-529, doi: https://doi.org/10.1126/science.117.3046.528.

2. S. L. Miller, Production of some organic compounds under possible primitive Earth conditions, J. Am. Chem. Soc. 77 (1955) 2351-2361, doi: https://doi.org/https://doi. org/10.1021/ja01614a001.

3. E. Wollrab, S. Scherer, F. Aubriet, V. Carré, T. Carlomagno, L. Codutti, A. Ott, Chemical analysis of a "Miller-type" complex prebiotic broth. Pat I: Chemical diversity, oxygen and nitrogen based polymers, Orig. Life Evol. Biosph. 46 (2016) 149-169, doi: https://doi.org/10.1007/s11084-015-9468-8.

4. F. Darwin, The Life and Letters of Charles Darwin. Vol II. Letter to Joseph Dalton Hooker, February 1, 1871, Basic Books, New York 1959, pp. 202-203.

5. J. Peretó, J. K. Bada, A. Lazcano, Charles Darwin and the origin of life, Orig. Life Evol. Biosph. 39 (2009) 395-406, doi: https://doi.org/10.1007/s11084-009-9172-7.

6. A. I. Oparin, The Origin of Life, Translated by S. Morgulis, $2^{\text {nd }}$ Ed. Dover Publ, Mineola, New York 1953.

7. M. Bernstein, Prebiotic materials from and off the early Earth, Phil. Trans. Roy. Soc. B 361 (2006) 1689-1702, doi: https:// doi.org/10.1098/rstb.2006.1913.

8. P. Thaddeus, The prebiotic molecules observed in the interstellar gas, Phil. Trans. Roy. Soc. B 361 (2006) 1681-1687, doi: https://doi.org/10.1098/rstb.2006.1897.

9. B. A. McGuire, P. B. Carroll, R. A. Loomis, I. A. Finneran, P. R. Jewell, A. J. Remijan, G. A. Blake, Discovery of the interstellar chiral molecule propylene oxide $\left(\mathrm{CH}_{3} \mathrm{CHCH}_{2} \mathrm{O}\right)$, Science 352 (2016) 1449-1452, doi: https://doi.org/10.1126/ science.aae0328.

10. P. Schmitt-Kopplin, Z. Gabelica, R. D. Gougeon, A. Fekete, B. Kanawati, M. Harir, I. Gebefuegi, G. Eckel, N. Hertkorn, High molecular diversity of extraterrestrial organic matter in Murchison meteorite revealed 40 years after its fall, Proc. Natl. Acad. Sci. USA 107 (2010) 2763-2768, doi: https:// doi.org/10.1073/pnas.0912157107.

11. C. Chyba, C. Sagan, Endogenous production, exogenous delivery and impact-shock synthesis of organic molecules: an inventory for the origins of life, Nature 355 (1992) 125-132, doi: https://doi.org/10.1038/355125a0.

12. H. C. Urey, On the early chemical history of the earth and the origin of life, Proc. Natl. Acad. Sci. USA 38 (1952) 351363, doi: https://doi.org/10.1073/pnas.38.4.351.

13. J. F. Kasting, M. T. Tazewell Howard, Atmospheric composition and climate on the early Earth, Phil. Trans. Roy. Soc. B 361 (2006) 1733 -1742, doi: https://doi.org/10.1098/ rstb.2006.1902.

14. D. Trail, E. B. Watson, N. D. Tailby, The oxidation state of Hadean magmas and implications for early Earth's atmosphere, Nature 480 (2011) 79-82, doi: https://doi.org/10.1038/nature10655.

15. H. Palme, The giant impact formation of the Moon, Science 304 (2004) 977-979, doi: https://doi.org/10.1126/ science. 1097059.

16. R. Stribling, S. L. Miller, Energy yields for hydrogen cyanide and formaldehyde synthesis: the $\mathrm{HCN}$ and amino acid concentrations in the primitive ocean, Orig. Life Evol. Biosph. 17 (1987) 261-273, doi: https://doi.org/10.1007/BF02386466.

17. H. J. Cleaves, J. H. Chalmers, A. Lazcano, S. L. Miller, J. L. Bada, Mineral-organic interfacial processes: potential roles in the origins of life, Orig. Life Evol. Biosph. 38 (2008) 105- 
115, doi: https://doi.org/10.1007/s11084-007-9120-3.

18. R. M. Hazen, D. Papineau, W. Bleeker, R. T. Downs, J. Ferry, T. McCoy, D. Sverjensky, H. Yang, Mineral evolution, Am. Mineralog. 93 (2008) 1693-1720, doi: https://doi.org/10.2138/ am.2008.2955.

19. B. S. Kamber, The evolving nature of terrestrial crust from the Hadean, through the Archaean, into the Proterozoic, Precamb. Res. 258 (2015) 48-82, doi: https://doi.org/10.1016/j. precambres.2014.12.007.

20. R. Pascal, A. Pross, The logic of life, Orig. Life Evol. Biosph. 46 (2016) 507-513, doi: https://doi.org/10.1007/s11084016-9494-1.

21. V. Vasas, C. Fernando, M. Santos, S. Kauffman, E. Szathmáry, Evolution before genes, Biol. Direct 7 (2012) 1-14, doi: https://doi.org/10.1186/1745-6150-7-1.

22. S. L. Miller, J. W. Schopf, A. J. Lazcano, Oparin's "Origin of Life": sixty years later, Mol. Evol. 44 (1997) 351-353, doi: https://doi.org/10.1007/PL00006153.

23. E. G. Nisbet, N. H. Sleep, The habitat and nature of early life, Nature 409 (2001) 1083-1091, doi: https://doi. org/10.1038/35059210.

24. U. Deichmann, L. Baeck, "Molecular" versus "colloidal": controversies in biology and biochemistry, Bull. Hist. Chem. 32 (2007) 105-118.

25. R. Egel, Origins and emergent evolution of life: the colloid microsphere hypothesis revisited, Orig. Life Evol. Biosph. 44 (2014) 87-110, doi: https://doi.org/10.1007/s11084-0149363-8.

26. A. I. Oparin, T. N. Evreinova, T. I. Larionova, I. M. Davidova, [Synthesis and disintegration of starch in coacervate drop], Dokl. Akad. Nauk SSSR 143 (1962) 980-983.

27. P. Walde, A. Goto, P. A. Monnard, M. Wessicken, P. L. Luisi, Oparin's reactions revisited: enzymic synthesis of poly(adenylic acid) in micelles and self-reproducing vesicles, J. Am. Chem. Soc. 116 (1994) 7541-7547, doi: https://doi. org/10.1021/ja00096a010.

28. P. Stano, P. Carrara, Y. Kuruma, T. P. de Souza, P. L. Luisi, Compartmentalized reactions as a case of soft-matter biotechnology: synthesis of proteins and nucleic acids inside lipid vesicles, J. Mater. Chem. 21 (2011) 18887-18902, doi: https:// doi.org/10.1039/c1jm12298c.

29. M. V. Dubina, S. Y. Vyazmin, V. M. Boitsov, E. N. Nikolaev, I. A. Popov, A. S. Kononikhin, I. E. Eliseev, Y. V. Natochin, Potassium ions are more effective than sodium ion in salt induced peptide formation, Orig. Life Evol. Biosph. 43 (2013) 109-117, doi: https://doi.org/10.1007/s11084-013-9326-5.

30. M. Garlero, R. Wieczorek, K. Adamala, A. Giorgy, M. E. Schininà, P. Stano, P. L. Luisi, Ser-His catalyses the formation of peptides and PNAs, FEBS Lett. 583 (2009) 153-156, doi: https://doi.org/10.1016/j.febslet.2008.11.052.

31. A. Brack, B. Barbier, Chemical activity of simple basic peptides, Orig. Life Evol. Biosph. 20 (1990) 139-144, doi: https://doi.org/10.1007/BF01808274.

32. S. Chessari, R. Thomas, F. Polticelli, P. L. Luisi, The production de novo folded proteins by stepwise chain elongation: a prebiotic chemical evolution of macromolecular sequences, Chem. Biodivers. 3 (2006) 1202-1210, doi: https://doi. org/10.1002/cbdv.200690121.

33. S. Chessari, P. L. Luisi, On evidence: the lack of evidence for prebiotic macromolecular synthesis, Orig. Life Evol. Biosph. 42 (2012) 411-419, doi: https://doi.org/10.1007/s11084012-9302-5.

34. K. Ikehara, Y. Omori, R. Arai, A. Hirose, A novel theory of the origin of genetic code: a GNC-SNS hypothesis, J. Mol. Evol. 54 (2002) 530-538, doi: https://doi.org/10.1007/s00239-
001-0053-6.

35. K. Ikehara, Pseudo-replication of [GADV]-proteins and the origin of life, Int. J. Mol. Sci. 10 (2009) 1525-1537, doi: https://doi.org/10.3390/ijms10041525.

36. K. Ikehara, [GADV]-protein world hypothesis and the origin of life, Orig. Life Evol. Biosph. 44 (2014) 299-302, doi: https://doi.org/10.1007/s11084-014-9383-4.

37. T. Oba, J. Fukushima, M. Maruyama, R. Iwamoto, K. Ikehara, Catalytic activities of [GADV]-peptides, Orig. Life Evol. Biosph. 34 (2005) 447-460, doi: https://doi.org/10.1007/ s11084-005-3519-5.

38. H. Yanagawa, K. Kojima, M. Ito, N. Handa, Synthesis of polypeptides by microwave heating I. Formation of polypeptides during repeated hydration-dehydration cycles and their characterization, J. Mol. Evol. 31 (1990) 180-186, doi: https://doi.org/10.1007/BF02109494.

39. M. Ito, N. Hanada, H. Yanagawa, Synthesis of polypeptides by microwave heating II. Function of polypeptides synthesized during repeated hydration-dehydration cycles, J. Mol. Evol. 31 (1990) 187-194, doi: https://doi.org/10.1007/ BF02109459.

40. A. Butlerow, Formation synthétique d'une substance sucrée, C. R. Acad. Sci. 53 (1861) 145-147.

41. A. Ricardo, M. A. Carrigan, A. N. Olcott, S. A. Benner, Borate minerals stabilize ribose, Science 303 (2004) 196, doi: https://doi.org/10.1126/science.1092464.

42. A. Ricardo, Bioorganic molecules in the cosmos and the origin of Darwinian molecular systems, Dissertation, University of Florida, 2004.

43. S. A. Benner, H. J. Kim, M. A. Carrigan, Asphalt, water and the prebiotic synthesis of ribose, ribonucleosides and RNA, Acc. Chem. Res. 45 (2012) 2025-2034, doi: https://doi. org/10.1021/ar200332w.

44. Y. Kebukawa, A. L. D. Kilcoyne, G. D. Cody, Exploring the potential formation of organic solids in chondrites and comets through polymerization of interstellar formaldehyde, Astrophys. J. 771 (2013) 1-12, doi: https://doi.org/10.1088/0004$637 X / 771 / 1 / 19$

45. Y. Kebukawa,Q. H. S. Chan, S. Tachibana, K. Kobayashi, M. E. Zolensky, One-pot synthesis of amino acid precursors with insoluble organic matter in planetesimals with aqueous activity, Sci. Adv. 3 (2017) e1602093, doi: https://doi. org/10.1126/sciadv.1602093.

46. P. Decker, H. Schweer, R. Pohlmann, Bioids: X. Identification of formose sugars, presumable prebiotic metabolites, using capillary gas chromatography/gas chromatography-mass spectrometry of $n$-butoxime trifluoroacetates on OV-225, J. Cromatogr. A 244 (1982) 281-291, doi: https://doi. org/10.1016/S0021-9673(00)85692-7.

47. H. Ito, Y. Kono, A. Machida, Y. Mitsumoto, K. Omori, N. Nakamura, Y. Kondo, K. Ishihara, Kinetic study of the complex formation of boric and boronic acids with mono- and diprotonated ligands, Inorg. Chim. Acta 344 (2003) 28-36, doi: https://doi.org/10.1016/S0020-1693(02)01268-9.

48. Y. Furukawa, M. Horiuchi, T. Kakegawa, Selective stabilization of ribose by borate, Orig. Life Evol. Biosph. 43 (2013) 353-261, doi: https://doi.org/10.1007/s11084-013-9350-5.

49. R. Scorei, V. M. Cimpoiaşu, Boron enhances the theromostability of carbohydrates, Orig. Life Evol. Biosph. 36 (2006) 1-11, doi: https://doi.org/10.1007/s11084-005-0562-1.

50. J. B. Lambert, S. A. Gurusamy-Thangavelu, K. Ma, The silicate-mediated formose reaction: bottom-up synthesis of sugar silicates, Science 327 (2010) 984-986, doi: https://doi. org/10.1126/science.1182669.

51. H.-J. Kim, S. A. Benner, Comment on "The silicate-mediated formose reaction: bottom-up synthesis of sugar silicates", 
Science 329 (2010) 902-a, doi: https://doi.org/10.1126/science.1188697.

52. J. B. Lambert, S. A. Gurusamy-Thangavelu, K. Ma, Response to comment on "The silicate-mediated formose reaction: bottom-up synthesis of sugar silicates", Science 329 (2010) 902-b, doi: https://doi.org/10.1126/science.1188978.

53. Abundance in the Universe of the elements, url: http://periodictable.com/Properties/A/UniverseAbundance.v.log.html.

54. E. Vangioni-Flam, M. Cassé, J. Audouze, Lithium-beryllium-boron: Origin andevolution, (1999), arXiv:astro-ph/9907171.

55. B. E. Prieur, Etude de I'activite prebiotique potentielle de l'acide borique, C. R. Acad. Sci. Paris Chemistry 4 (2001) 667-670, doi: https://doi.org/10.1016/S13871609(01)01266-X.

56. J. Floor Antonini, The chemical composition of seawater, (2006), url: http://www.seafriends.org.nz/oceano/seawater. htm.

57. W. Heijlen, P. W. U. Appel, M. L. Frezzotti, A. Horsewell, J. L. R. Touret, Metamorfic fluid flow in the northeastern part of the 3.8-3.7 Ga Isua Greenstone Belt (SW Greenland): a re-evaluation of fluid inclusion evidence for early Archean seafloor-hydrothermal systems, Geochim. Cosmochim. Acta 70 (2006) 3075-3095, doi: https://doi.org/10.1016/j. gca.2006.04.005.

58. M. Zhai, D. M. Shaw, Boron cosmochemistry. Part I: Boron in meteorites, Meteoritics 29 (1994) 607-615, doi: https://doi. org/10.1111/j.1945-5100.1994.tb00773.

59. E. Grew, R. M. Hazen, Evolution of the minerals of beryllium, a quintessential crustal element (Abstract), Geological Society of America Abstracts with Programs 41 (2009) 99, url: https://gsa.confex.com/gsa/2009AM/finalprogram/abstract_161608.htm.

60. E. Grew, R. M. Hazen, Evolution of the minerals of beryllium, and comparison with boron mineral evolution (Abstract), Geological Society of America Abstracts with Programs 42 (2010) 199.

61. E. Grew, R. M. Hazen, Evolution of boron minerals: Has early species diversity been lost from the geological record? (Abstract), Geological Society of America, Abstracts with Programs 42 (2010) 92.

62. N. Kitadai, Dissolved divalent metal and $\mathrm{pH}$ effects on amino acid polymerization: A thermodynamic evaluation, Orig. Life Evol. Biosph. 47 (2017) 13-37, doi: https://doi. org/10.1007/s1184-016-9510-5.

63. H. Sawai, K. Kuroda, T. Hojo, Uranyl ion as a highly effective catalyst for internucleotide bond formation, Bull. Chem. Soc. Jpn. 62 (1989) 2018-2013, doi: https://doi.org/10.1246/ bcsj.62.2018.

64. H. Sawai, K. Higa, K. Kuroda, Synthesis of cyclic and acyclic oligocytidylates by uranyl ion catalyst in aqueous solution, J. Chem. Soc. Perkin Trans. 1 (1992) 505-508, doi: https://doi. org/10.1039/P19920000505.

65. H. Sawai, Catalysis of internucleotide bond formation by divalent metal ions, J. Am. Chem. Soc. 98 (1976) 7037-7039, doi: https://doi.org/10.1021/ja00438a050.

66. H. Sawai, K. Yamamoto, Lanthanide ion as a catalyst for internucleotide bond formation, Bull. Chem. Soc. Jpn. 69 (1996) 1701-1704, doi: https://doi.org/10.1246/bcsj.69.1701.

67. H. L. Sleeper, R. Lohrmann, L. E. Orgel, Template-directed synthesis of oligoadenylates catalyzed by $\mathrm{Pb}^{2+}$ ions, J. Mol. Evol. 13 (1979) 203-214, doi: https://doi.org/10.1007/ BF01739480.

68. R. Lohrmann, P. K. Bridson, L. E. Orgel, Efficient metal-ion catalyzed template-directed oligonucleotide synthesis, Science 208 (1980) 1464-1465.
69. J. D. Bernal, The physical basis of life, Proc. Phys. Soc. A 62 (1949) 537-558.

70. C. Ponnamperuma, A. Shimoyama, E. Friebele, Clay and the origin of life, Orig. Life Evol. Biosph. 12 (1982) 9-40, doi: https://doi.org/10.1007/BF00926908.

71. F. Poulet, J. P. Bibring, J. F. Mustard, A. Gendrin, N. Mangold, Y. Legevin, R. E. Arvidson, B. Gondet, C. Gomez, Omega Team, Phyllosilicates on Mars and implications for early Martian climate, Nature 438 (2005) 623-627, doi: https://doi. org/10.1038/nature04274.

72. D. T. Vaniman, D. L. Bish, D. W. Ming, T. F. Bristow, R. V. Morris, D. F. Blake, S. J. Chipera, S. M. Morrison, A. H. Treiman, E. B. Rampe, M. Rice, C. N. Achilles, J. P. Grotzinger, S. M. McLennan, J. Williams, J. F. Bell III, H. E. Newsom, R. T. Downs, S. Maurice, P. Sarrazin, A. S. Yen, J. M. Morookian, J. D. Farmer, K. Stack, R. E. Milliken, B. L. Ehlmann, D. Y. Sumner, G. Berger, J. A. Crisp, J. A. Hurowitz, R. Anderson, D. J. Des Marais, E. M. Stolper, K. S. Edgett, S. Gupta, N. Spanovich, MSL Science Team, Mineralogy of a Mudstone and Yellowknife Bay, Gale Crater, Mars, Science 343 (6169) (2014) Art 1243480, doi: https://doi.org/10.1126/science.1243480.

73. V. K. Pearson, M. A. Sephton, A. T. Kearsley, P. A. Bland, I. A. Franchi, I. Gilmour, Clay mineral-organic matter relationships in the early solar system, Meteorit. Planet. Sci. 37 (2002) 1829-1833, doi: https://doi.org/10.1111/j.1945-5100.2002. tb01166.x.

74. D. Takir, J. P. Emery, H. Y. Mcsween, C. A. Hibbitts, R. N. Clark, N. Pearson, A. Wang, Nature and degree of aqueous alteration in $\mathrm{CM}$ and $\mathrm{Cl}$ carbonaceous chondrites, Meteorit. Planet. Sci. 48 (2013) 1618-1637, doi: https://doi.org/10.1111/ maps.12171.

75. M. C. De Sanctis, E. Ammannito, A. Raponi, S. Marchi, T. B. McCord, H. Y. McSween, F. Capaccioni, M. T. Capria, F. G. Carrozzo, M. Ciarniello, A. Longobardo, F. Tosi, S. Fonte, M. Formisano, A. Frigeri, M. Giardino, G. Magni, E. Palomba, D. Turrini, F. Zambon, J.-P. Combe, W. Feldman, R. Jaumann, L. A. McFadden, C. M. Pieters, T. Prettyman, M. Toplis, C. A. Raymond, C. T. Russell, Ammoniated phyllosilicates with a likely outer Solar System origin on (1) Ceres, Nature 528 (2015) 241-244, doi: https://doi.org/10.1038/nature16172.

76. W. M. Napier, J. T. Wickramasinghe, N. C. Wickramasinghe, The origin of life in comets, Int. J. Astrobiol. 6 (2007) 321323, doi: https://doi.org/10.1017/S1473550407003941.

77. M. D. Nikalje, P. Puhukan, A. Sudalai, Recent advances in clay-catalyzed organic transformations, Org. Prep. Proced. Internat. 32 (2000) 1-40, doi: https://doi. org/10.1080/00304940009356743.

78. S. Dasgupta, B. Török, Application of clay catalysts in organic synthesis. A review, Org. Prep. Internat. 40 (2008) 1-65, doi: https://doi.org/10.1080/003049408093556640.

79. J. F. Lambert, Adsorption and polymerization of amino acids on mineral surfaces: A review, Orig. Life Evol. Biosph. 38 (2008) 211-242, doi: https://doi.org/10.1007/s11084-0089128-3.

80. J. R. Collins, G. H. Loew, B. T. Luke, D. H. White, Theoretical investigation of the role of clay edges in prebiotic peptide bond formation, Orig. Life Evol. Biosph. 18 (1988) 107-119, doi: https://doi.org/10.1007/BF01808785.

81. T. Qui, M. A. Barteau, STM study of glycine on $\mathrm{TiO}_{2}(111)$ single crystal surfaces, J. Coll. Interf. Sci. 303 (2007) 229-235, doi: https://doi.org/10.1016/j.jcis.2006.07.053.

82. J. G. Mesu, T. Visser, A. M. Beale, F. Soulimani, B. M. Weckhuysen, Host-guest chemistry of copper(II) histidine complexes encaged in zeolite Y, Chem. Eur. J. 12 (2006) $7167-$ 7177, doi: https://doi.org/10.1002/chem.200600087.

83. N. N. Vlasova, L. P. Golovkova, The adsorption of amino ac- 
ids on the surface of highly dispersed silica, Coll. J. 66 (2004) 657-662, doi: https://doi.org/10.1007/s10595-005-0042-3.

84. A. Rimola, S. Tosoni, M. Sodupe, P. Ugliengo, Does silica surface catalyze peptide bond formation? New insights from first-principles calculations, Chem. Phys. Chem. 7 (2006) 157-163, doi: https://doi.org/10.1002/cphc.200500401.

85. W. Zheng, J. Zhou, Z. Zhang, L. Chen, Z. Zhang, Y. Li, N. $M a, P$. Du, Formation of intercalation compounds on kaolinite-glycine via displacing guest water by glycine, J. Colloid. Interface Sci. 432 (2014) 278-284, doi: https://doi. org/10.1016/j.jcis.2014.06.016.

86. M. Sodupe, A. Rimola, P. Ugliengo, Adsorción y polimerización de aminoácidos en superficies de minerals, An. Quim. 107 (2011) 137-143.

87. J. Bujdák, B. M. Rode, Silica, alumina, and clay-catalyzed alanine peptide bond formation, J. Mol. Evol. 45 (1997) $457-$ 466, doi: https://doi.org/10.1007/PL00006250.

88. J. G. Lawless, N. Levi, The role of metal ions in chemical evolution: polymerization of alanine and glycine in a cation-exchanged clay environment, J. Mol. Evol. 13 (1979) 281-286, doi: https://doi.org/10.1007/BF01731368.

89. M. Meng, L. Stievano, J. F. Lambert, Adsorption and thermal condensation mechanisms of amino acids on oxide supports. I. Glycine on silica, Langmuir 20 (2004) 914-923, doi: https://doi.org/10.3866/PKU.WHXB20070107.

90. E. T. Degens, J. Matheja, T. A. Jackson, Template catalysis: asymmetric polymerization of amino acids on clay minerals, Nature 227 (1970) 492-493, doi: https://doi. org/10.1038/227492a0.

91. T. A. Jackson, Evidence for the selective adsorption and polymerization of the L-optical isomers of amino acids relative to D-optical isomers on the edge faces of kaolinite, Experientia 27 (1971) 242-243, doi: https://doi.org/10.1007/ BF02138119.

92. W. A. Bonner, J. Flores, On the asymmetric adsorption of phenylalanine enantiomers by kaolin, Curr. Modern Biol. 5 (1973) 103-113, doi: https://doi.org/10.1016/03032647(73)90018-x.

93. B. Siffert, A. Naidja, Stereoselectivity of montmorillonite in the adsorption and deamination of some amino acids, Clay Minerals 27 (1992) 109-118, doi: https://doi.org/10.1180/ claymin.1992.027.1.11.

94. R. M. Hazen, T. R. Filley, G. A. Goodfriend, Selective adsorption of L- and D-amino acids on calcite: implication for biochemical homochirality, Proc. Natl. Acad. Sci. USA 98 (2001) 5487-5490, doi: https://doi.org/10.1073/pnas.101085998.

95. A. Yamagishi, Chirality recognition of a clay surface modified by an optically active metal chelate, J. Chem. Soc. Dalton Trans. 0 (4) (1983) 679-681, doi: https://doi.org/10.1039/ DT9830000679.

96. A. Yamagishi, Optical resolution and asymmetric syntheses by use of adsorption on clay minerals, J. Coord. Chem. 16 (1987) 131-211, doi: https://doi.org/10.080/00958978708081202.

97. J. Bujdák, B. M. Rode, Silica, alumina, and clay catalyzed peptide bond formation: enhanced efficiency of alumina catalyst, Orig. Life Evol. Biosph. 29 (1999) 451-461, doi: https://doi.org/10.1023/A:1006524703513.

98. N. Kitadai, H. Oonishi, K. Umemoto, T. Usui, K. Fukushi, S. Nakashima, Glycine polymerization on oxide minerals, Orig. Life Evol. Biosph. 47 (2) (2017) 123-143, doi: https://doi. org/10.1007/s11084-016-9516-z.

99. G. Martra, C. Deiana, Y. Sakhno, I. Barberis, M. Fabbiani, M. Pazzi, M. Vincenti, The formation and self-assembly of long prebiotic oligomers produced by condensation of unactivated amino acids on oxide surfaces, Angew. Chem. Int.
Ed. 53 (2014) 4671-7674, doi: https://doi.org/10.1002/ anie.201311089.

100.H. J. Cleaves II, A. M. Scott, F. C. Hill, J. Leszczynski, N. Sahai, $R$. Hazen, Mineral-organic interfacial processes: potential roles in the origins of life, Chem. Soc. Rev. 41 (2012) 55025525, doi: https://doi.org/10.1039/C2CS35112A

101.G. Ertem, Montmorillonite, oligonucleotides, RNA and origin of life, Orig. Life Evol. Biosph. 34 (2004) 549-570, doi: https://doi.org/10.1023/B:ORIG.0000043130.49790.a7.

102.J. P. Ferris, Montmorillonite-catalysed formation of RNA oligomers: the possible role of catalysis in the origins of life, Phil. Trans. Roy. Soc. B 361 (2006) 1777-1786, doi: https:// doi.org/10.1098/rstb.2006.1903.

103.W. Gilbert, The RNA world, Nature 319 (1986) 618, doi: https://doi.org/10.1038/319618a0.

104.G. F. Joyce, RNA evolution and the origins of life, Nature 338 (1989) 217-224, doi: https://doi.org/10.1038/338217a0.

105.T. R. Gestland, T. R. Cech, J. F. Atkins, The RNA world, Cold Spring Harbor Press, New York, NY, 1999.

106.F. H. Westheimer, Why nature chose phosphates, Science 235 (1987) 1173-1178, doi: https://doi.org/10.1126/science.2434996.

107.A. W. Schwartz, Phosphorus in prebiotic chemistry, Phil. Trans. Roy. Soc. B 361 (2006) 1743-1749, doi: https://doi. org/10.1098/rstb.2006.1901.

108.H. D. Bean, Y, Sheng, J. P. Collins, F. A. L. Anet, J. Leszczynski, N. V. Hud, Formation of pyrimidine nucleoside by a free pyrimidine base and ribose in plausible prebiotic reaction, J. Am. Chem. Soc. 129 (2007) 9556-9557, doi: https://doi. org/10.1021/ja072781a.

109.Y. Yamagata, H. Watanabe, M. Saitoh, T. Namba, Volcanic production of polyphosphates and its relevance to prebiotic evolution, Nature 352 (1991) 516-519, doi: https://doi. org/10.1038/352516a0

110.R. M. De Graaf, J. Visscher, A. W. Schwartz, A plausibly prebiotic synthesis of phosphonic acids, Nature 378 (1995) 474477, doi: https://doi.org/10.1038/378474a0.

111. M. A. Pasek, Schreibersite on the early Earth: Scenarios for prebiotic phosphorylation, Geosci. Front. 8 (2017) 329-335, doi: https://doi.org/10.1016/j.gsf.2016.06.008.

112.S. Miyakawa, J. P. Ferris, Sequence and regioselectivity in the montmorillonite-catalyzed synthesis of RNA, J. Am. Chem. Soc. 125 (2003) 8202-8208, doi: https://doi.org/10.1021/ ja034328e.

113.J. P. Ferris, The synthesis of the first polyribonucleotides: the role of catalysis, Chem. Tract. Biochem. Mol. Biol. 12 (1999) 419-431.

114.P. C. Joshi, S. Pitsch, J. P. Ferris, Homochiral selection in the montmorillonite-catalyzed and uncatalyzed prebiotic synthesis of RNA, Chem. Comm. 0 (24) (2000) 2497-2498, doi: https://doi.org/10.1039/B007444F.

115.P. C. Joshi, S. Pitsch, J. P. Ferris, Selectivity of montmorillonite catalyzed prebiotic reactions of D,L-nucleotides, Orig. Life Evol. Biosph. 37 (2007) 3-26, doi: https://doi.org/10.1007/ s11084-006-9013-x.

116.P. C. Joshi, M. F. Aldersley, J. P. Ferris, Homochiral selectivity in RNA synthesis: montmorillonite-catalyzed quaternary reaction of $D, L$-purine with $D, L$-pyrimidine nucleotides, Orig. Life Evol. Biosph. 41 (2011) 213-236, doi: https://doi. org/10.1007/s11084-010-9222-1.

117.P. C. Joshi, M. F. Aldersley, J. P. Ferris, Progress in demonstrating homochiral selection in prebiotic RNA synthesis, Adv. Space Res. 51 (2013) 772-779, doi: https://doi. org/10.1016/j.asr.2012.09.036. 
118.P. C. Joshi, M. F. Aldersley, J. W. Delano, J. P. Ferris, Mechanism of montmorillonite catalysis in the formation of RNA oligomers, J. Am. Chem. Soc. 131 (2009) 13369-13374, doi: https://doi.org/10.1021/ja9036516.

119.M. F. Aldersley, P. C. Joshi, RNA dimer synthesis using montmorillonite as a catalyst: the role of surface layer charge, Appl. Clay Sci. 83-84 (2013) 77-82, doi: https://doi.org/10.1016/j. clay.2013.08.009.

120.M. F. Aldersley, P. C. Joshi, J. D. Price, J. P. Ferris, The role of montmorillonite in its catalysis of RNA synthesis, App. Clay Sci. 54 (2011) 1-14, doi: https://doi.org/10.1016/j. clay.2011.06.011.

121.K. J. Wang, J. P. Ferris, Effect of inhibitors on the montmorillonite clay-catalyzed formation of RNA: studies of the reaction pathway, Orig. Life Evol. Biosph. 31 (2001) 381-402, doi: https://doi.org/10.1023/A:1011813831394.

122.P. C. Joshi, M. F. Aldersley, Significance of mineral salts in prebiotic RNA synthesis catalyzed by montmorillonite, J. Mol. Evol. 76 (2013) 371-379, doi: https://doi.org/10.1007/ s00239-013-9568-x.

123.L. P. Knauth, Salinity history of the Earth's early ocean, Nature 395 (1998) 554-555, doi: https://doi.org/10.1038/26879.

124. G. D. Cody, Transition metal sulfides and the origin of metabolism, Annu. Rev. Earth Planet. Sci. 32 (2004) 569-599, doi: https://doi.org/10.1146/annurev.earth.32.101802.120225.

125.G. Wächtershäuser, Groundworks for an evolutionary biochemistry - the iron-sulfur world, Progr. Biophys. Mol. Biol. 58 (1992) 85-201, doi: https://doi.org/10.1016/00798107(92)90022-X.

126.G. Wächtershäuser, From volcanic origins of chemoautotrophic life to Bacteria, Archaea and Eukarya, Phil. Trans. Roy. Soc. B 361 (2006) 1787-1808, doi: https://doi.org/10.1098/ rstb.2006.1904.

127.G. Wächtershäuser, On the chemistry and evolution of pioneer organism, Chem. Biodiv. 4 (2007) 584-602, doi: https://doi.org/10.1002/cbdv.200790052.

128.G. Wächtershäuser, Pyrite formation, the first energy source for life: a hypothesis, Syst. Appl. Microbiol. 10 (1988) $207-$ 210, doi: https://doi.org/10.1016/S0723-2020(88)80001-8.

129.E. Blöchl, M. Keller, G. Wächtershäuser, K. O. Stetter, Reactions depending on iron sulfide and linking geochemistry with biochemistry, Proc. Natl. Acad. Sci. USA 89 (1992) 8117-8120, doi: https://doi.org/10.1073/pnas.89.17.8117.

130.D. O. Hall, R. Cammack, K. K. Rao, Role for ferredoxins in the origin of life and biological evolution, Nature 233 (1971) 136-138, doi: https://doi.org/10.1038/233136a0.

131.D. C. Rees, J. B. Howard, The interface between the biological and inorganic worlds: iron-sulfur metalloclusters, Science 300 (2003) 929-930, doi: https://doi.org/10.1126/ science. 1083075.

132.C. H. Lillig, R. Lill, Light on iron-sulfur clusters, Chem. Biol. 16 (2009) 11213-1214, doi: https://doi.org/10.1016/j. chembiol.2009.12.005.

133.J. Kim, D. C. Rees, Structural models for the metal centers in the nitrogenase molybdenum-iron protein, Science 257 (1992) 1677-1682, doi: https://doi.org/10.1126/science.1529354.

134.R. Österberg, Origins of metal ions in biology, Nature 249 (1974) 382-383, doi: https://doi.org/10.1038/249382a0.

135. K. O. Stetter, Hyperthermophiles in the history of life, Phil. Trans. Roy. Soc. B 361 (2006) 1837-1843, doi: https://doi. org/10.1098/rstb.2006.1907.

136.L. J. Rothschild, R. L. Mancinelli, Life in extreme environments, Nature 409 (2001) 1092-1101, doi: https://doi. org/10.1038/35059215.

137.M. J. Russell, A. J. Hall, A. G. Cairns-Smith, P. S. Braterman, Submarine hot springs and the origin of life, Nature 336 (1988) 117, doi: https://doi.org/10.1038/336117b0.

138.D. S. Kelley, J. A.Karson, D. K. Blackman, G. L.Früh-Green, D. A. Butterfield,M. D. Lilley, E. J. Olson, M. O. Schrenk, K. K. Roe, G. Lebon, G. et al., An off-axis hydrothermal vent field near the Mid-Atlantic Ridge at 30 N, Nature 412 (2001) 145-149, doi: https://doi.org/10.1038/35084000.

139.E. G. Nisbet, C. M. R. Fowler, The early history of life. Treatise of geochemistry, vol. 8 (ed. H. D. Holland HD, Turekian KK), Elsevier, Amsterdam, 2004, pp. 1-39.

140.C. S. Cockell, The origin and emergence of life under impact bombardment, Phil. Trans. Roy. Soc. B 361 (2006) 18451856, doi: https://doi.org/10.1098/rstb.2006.1908.

141.T. Gold, The deep, hot biosphere, Proc. Natl. Acad. Sci. USA 89 (1992) 6045-6049, doi: https://doi.org/10.1073/ pnas.89.13.6045.

142.J. A. Baross, S. E. Hoffman, Submarine hydrothermal vents and associated gradient environments as sites for the origin and evolution of life, Orig. Life Evol. Biosph. 15 (1985) $327-$ 345, doi: https://doi.org/10.1007/BF01808177.

143.M. J. Russell, A. J. Hall, The emergence of life from iron monosulphide bubbles at a submarine hydrothermal redox and $\mathrm{pH}$ front, J. Geol. Soc. 154 (1997) 377-402, doi: https:// doi.org/10.1144/gsjgs154.3.0377.

144.M. J. Russell, A. J. Hall, In vitro growth of iron sulfide chimneys: possible culture chambers for origin-of-life experiments, Terra Nova 1 (1989) 238-241, doi: https://doi. org/10.111/j.1365-3121.1989.tb00364.x.

145.L. M. Barge, S. S. S. Cardoso, J. H. E. Cartwright, G. J. T. Cooper, L. Cronin, A. De Wit, I. J. Doloboff, B. Escribano, R. E. Goldstein, F. Haudin, D. E. H. Jones, A. L. Mackay, J. Maselko, J. J. Pagano, J. Pantaleone, M. J. Russell, C. Ignacio SainzDíaz, O. Steinbock, D. A. Stone, Y. Tanimoto, N. L. Thomas, From chemical gardens to chemobrionics, Chem. Rev. 115 (2015) 8652-8703, doi: https://doi.org/10.1021/acs.chemrev.5b00014.

146.R. Saladino, V. Neri, C. Crestini, G. Costanzo, M. Graciotti, E. Di Mauro, Synthesis and degradation of nucleic acid components by formamide and iron sulfur minerals, J. Am. Chem. Soc. 130 (2008) 15512-15518, doi: https://doi. org/10.1021/ja804782.

147. M. G. Vladimirov, Y. F. Ryzhkov, V. A. Alekseev, V. A. Bogdanovskaya, V. A. Otroschenko VA, M. S. Kritsky, Electrochemical reduction of carbon dioxide on pyrite as a pathway for abiogenic formation of organic molecules, Orig. Life Evol. Biosph. 34 (2004) 347-360, doi: https://doi.org/10.1023/B:ORIG.0000029883.18365.af.

148. A. Roldan, N. Hollingsworth, A. Roffey, H. U. Islam, J. B. M. Goodall, C. R. A. Catlow, J. A. Darr, W. Bras, G. Sankar, K. B. Holt, G. Hogarth, N. H. de Leeuw, Bio-inspired $\mathrm{CO}_{2}$ conversion by iron sulfide catalysts under sustainable conditions, Chem. Comm. 51 (35)(2015) 7501-7504, doi: https://doi. org/10.1039/c5cc02078f.

149.D. P. Summers, Ammonia formation by reduction of nitrite/ nitrate by FeS: ammonia formation under acidic conditions, Orig. Life Evol. Biosph. 35 (2005) 299-312, doi: https://doi. org/10.1007/s11084-005-2040-1.

150.M. Dörr, J. Käßbohrer, R. Grunert, G. Kreisel, W. A. Brand, R. A. Werner, H. Geilmann, C. Apfel, W. Robl, Eine mögliche präbiotische Bildung von Ammoniak aus molekularem Stickstoff auf Eisensulfidoberflächen, Angew. Chem. 115 (2003) 1579-1581, doi: https://doi.org/10.1002/ange.200250371.

151.W. Heinen, A. M. Lauwers, Organic sulfur compounds re- 
sulting from the interaction of iron sulfide and carbon dioxide in an anaerobic aqueous environment, Orig. Life Evol. Biosph. 26 (1996) 131-150, doi: https://doi.org/10.1007/ BF01809852.

152.G. D. Cody, N. Z. Boctor, T. R. Filley, R. M. Hazen, J. H. Scott, A. Sharma, H. S. Yoder Jr., Primordial carbonylated iron-sulfur compounds and the synthesis of pyruvate, Science 289 (2000) 1337-1340, doi: https://doi.org/10.1126/ science.289.5483.1337.

153.D. Hafenbradl, M. Keller, G. Wächtershäuser, K. O. Stetter, Primordial amino acids by reductive amination of $\alpha$-oxo acids in conjuction with oxidative formation of pyrite, Tetrahedron Lett. 36 (1995) 5179-5182, doi: https://doi. org/10.1016/0040-4039(95)01008-6.

154.C. Huber, G. Wächtershäuser, Primordial reductive amination revisited, Tetrahedron Lett. 44 (2003) 1695-1697, doi: https://doi.org/10.1016/S0040-4039(02)02863-0.

155.C. Huber, G. Wächtershäuser, Peptides by activation of amino acids with $\mathrm{CO}$ on $(\mathrm{Ni}, \mathrm{Fe}) \mathrm{S}$ surfaces and implications for the origin of life, Science 281 (1998) 670-682, doi: https:// doi.org/10.1016/S0040-4039(02)02863-0.

156.G. Wächtershäuser, Evolution of the first metabolic cycles, Proc. Natl. Acad. Sci. USA 87 (1990) 200-204, doi: https:// doi.org/10.1073/pnas.87.1.200.

157.V. Sojo, B. Herschy, A. Whicher, E. Camprubí, N. Lane, The origin of life in alkaline hydrothermal vents, Astrobiology 16 (2016) 1-17, doi: https://doi.org/10.1089/ast.2015.1406.

158.D. J. Berriford, C. Bolm, K. B. Sharpless, Ligand-accelerated catalysis, Angew. Chem. Int. Ed. 34 (1995) 1059-1070, doi: https://doi.org/10.1002/anie.199510591.

159.M. M. Hanczyc, S. M. Fujikawa, J. W. Szostak, Experimental models of primitive cellular components: Encapsulation, growth, and division, Science 302 (2003) 618-622, doi: https://doi.org/10.1126/science.1089904.

160.M. M. Hanczyc, S. S. Mansy, J. W. Szostak, Mineral surface directed membrane assembly, Orig. Life Evol. Biosph. 37 (2007) 67-82, doi: https://doi.org/10.1007/s11084-0069018-5.

161.A. D. Keefe, S. L. Miller, G. McDonald, J. Bada, Investigation of the prebiotic synthesis of amino acids and RNA beses from $\mathrm{CO}_{2}$ using $\mathrm{FeS} / \mathrm{H}_{2} \mathrm{~S}$ as a reducing agent, Proc. Natl. Acad. Sci. USA 92 (1995) 11904-11906, doi: https://doi.org/10.1073/ pnas.92.25.11904.

162.C. Del Bianco, S. S. Mansy, Nonreplicating protocells, Acc. Chem. Res. 45 (2012) 2125-2130, doi: https://doi. org/10.1021/ar300097w.

163.S. Mann, Systems of creation: the emergence of life from nonliving matter, Acc. Chem. Res. 45 (2012) 2131-2141, doi: https://doi.org/10.1021/ar200281t.

164.S. Zhang, Lipid-like self-assembling peptides, Acc. Chem. Res. 45 (2012) 2142-2150, doi: https://doi.org/10.1021/ ar300034w.

165.D. E. Canfield, M. T. Rosing, C. Bjerrum, Early anaerobic metabolisms, Phil. Trans. Roy. Soc. B 361 (2006) 1819-1836, doi: https://doi.org/10.1098/rstb.2006.1906.

166.M. S. Dodd, P. Papineau, T. Grenne, J. F. Slack, M. Rittner, F. Pirajno, J. O’Neil, C. T. S. Little, Evidence for early life in Earth's oldest hydrothermal vent precipitates, Nature $\mathbf{5 4 3}$ (2017) 60-65, doi: https://doi.org/10.1038/nature21377.

167. N. Kitadai, Energetics of amino acid synthesis in alkaline hydrothermal environments, Orig. Life Evol. Biosph. 45 (2015) 377-409, doi: https://doi.org/10.1007/s11084-015-9428-3.

168.S. A. Kauffman, Approaches to the origin of life on Earth, Life 1 (2011) 34-48, doi: https://doi.org/10.3390/life1010034.

169.M. Santosh, T. Arai, S. Maruyama, Hadean Earth and primordial continents: The cradle of prebiotic life, Geosci.
Front. 8 (2017) 309-327, doi: https://doi.org/10.1016/j. gsf.2016.07.005.

170.D. Deamer, S. Singaram, S. Rajamani, V. Kompanichenko, S. Guggenheim, Self-assembly processes in the prebiotic environment, Phil. Trans. Roy. Soc. B 361 (2006) 1809-1818, doi: https://doi.org/10.1098/rstb.2006.1905.

171.K. A. Maher, D. J. Stevenson, Impact frustration of the origin of life, Nature 331 (1988) 612-614, doi: https://doi. org $/ 10.1038 / 331612 \mathrm{a} 0$

172. N. H. Sleep, K. J. Zahnle, J. F. Kasting, H. J. Morowitz, Annihilation of ecosystems by large asteroid impacts on the early Earth, Nature 342 (1989) 139-142, doi: https://doi. org/10.1038/342139a0.

173.N. W. Gabel, C. Ponnamperuma, Models for origin of monosaccharides: synthesis of sugars in potentially prebiotic conditions, Nature 216 (1967) 453-455, doi: https://doi. org/10.1038/216453a0.

174.S. L. Miller, The prebiotic synthesis of organic molecules and polymers, Adv. Chem. Phys. 55 (1984) 85-107, doi: https:// doi.org/10.1002/9780470142790.ch7.

175.N. Lahav, D. White, S. Chang, Peptide formation in prebiotic era: thermal condensation of glycine in fluctuating clay environments, Science 201 (1978) 67-69, doi: https://doi. org/10.1126/science.663639.

176.M. Meng, L. Y. Xia, L. H. Guo, Adsorption and thermal condensation of glycine on kaolinite, Acta Phys-Chim. Sin. 23 (2007) 32-36, doi: https://doi.org/10.3866/PKU. WHXB20070107.

177.P. Dalai, H. L. Pleyer, H. Strasdeit, S. Fox, The influence of mineral matrices on the thermal behavior of glycine, Orig. Life Evol. Biosph. (2016) 1-26, doi: https://doi.org/10.1007/ s11084-016-9523-0.

178.J. Bujdák, H. Slosiarikova, N. Textler, M. Schwendinger, B. M. Rode, On the possible role of montmorillonites in prebiotic peptide formation, Montsh. Chem. 125 (1994) 1033-1039, doi: https://doi.org/10.1007/BF00811510.

179.J. P. Ferris, A. R. Hill Jr, R. Liu, L. E. Orgel, Synthesis of long prebiotic oligomers on mineral surfaces, Nature 381 (1996) 59-61, doi: https://doi.org/10.1038/381059a0.

180.A. R. Hill Jr, C. Böhler, L. E. Orgel, Polymerizaton on rocks: negatively-charged alpha-amino acids, Orig. Life Evol. Biosph. 28 (1998) 235-243, doi: https://doi. org/10.1023/A:1006572112311.

181.D. H. White, R. M. Kennedy, J. Macklin, Acyl silicates and acyl aluminates as activated intermediates in peptide formation on clays, Orig. Life 14 (1984) 273-278, doi: https://doi. org/10.1007/BF00933668.

182. T. L. Porter, M. P. Eastman, E. Bain, S. Begay, Analysis of peptides synthesized in the presence of Saz-1 montmorillonite and $\mathrm{Cu}^{2+}$ exchanged hectorite, Biophys. Chem. 91 (2001) 115124, doi: https://doi.org/10.1016/S0301.4622(01)00159-1.

183.J. P. Ferris, G. Ertem, V. Agarwal, Mineral catalysis of the formation of dimers of $5^{\prime}$-AMP in aqueous solution: the possible role of montmorillonite clays in the prebiotic synthesis of RNA, Orig. Life Evol. Biosph. 19 (1989) 165-178, doi: https://doi.org/10.1007/BF01808150.

184.P. Z. Ding, K. Kawamura, J. P. Ferris, Oligomerization of uridine phosphoimidazolides on montmorillonite: A model for the prebiotic synthesis of RNA on minerals, Orig. Life Evol. Biosph. 26 (1996) 151-171, doi: https://doi.org/10.1007/ BF01809853.

185.K. Kawamura, J. P. Ferris, Clay catalysis of oligonucleotide formation: Kinetics of the reaction of the 5 '-phosphorimidazolides of nucleotides with the non-basic heterocycles uracil and hypoxanthine, Orig. Life Evol. Biosph. 29 (1999) 563-591, doi: https://doi.org/10.1023/A:1006648524187.

186.G. Ertem, J. P. Ferris, Synthesis of RNA oligomers on heterogenous templates, Nature 379 (1996) 238-240, doi: https:// doi.org/10.1038/379238a0.

187.J. P. Ferris, G. Ertem, Oligomerization reactions of ribonucleotides: The reaction of the 5'-phosphorimidozolide of adenosine with diadenosine pyrophosphate on montmoril- 
lonite and other minerals, Orig. Life Evol. Biosph. 23 (1993) 229-241, doi: https://doi.org/10.1007/BF01581901.

188.W. Huang, J. P. Ferris, Synthesis of 35-40 mers of RNA oligomers from unblocked monomers, Chem. Comm. 12 (2003) 1458-1459, doi: https://doi.org/10.1039/B303134A.

189.W. Huang, J. P. Ferris, One-step, regioselective synthesis of up to 50-mers of RNA oligomers by montmorillonite catalysis, J. Am. Chem. Soc. 128 (2006) 8914-8919, doi: https:// doi.org/10.1021/ja061782k.
190. K. M. Coari, R. C. Martin, K. Jain, L. B. McGown, Nucleotide selectivity in abiotic RNA polymerization reactions, Orig. Life Evol. Biosph. 48 (2017) 1-17, doi: https://doi.org/10.1007/ s11084-017-9532-7.

191.P. C. Joshi, K. Dubey, M. F. Aldersley, M. Sausville, Clay catalyzed RNA synthesis under Martian conditions: Application for Mars return sample. Biochem. Biophys. Res. Commun. 462 (2015) 99-104, doi: https://doi.org/10.1016/j. bbrc.2015.04.044.

\section{SAŽETAK}

\section{Kataliza u prvotnom svijetu \\ Nenad Raos ${ }^{a^{*}}$ i Vladimir Bermanec ${ }^{b}$}

Kataliza omogućuje uređenu sintezu te njezinu evoluciju do autokatalitičkih (samoreproduktivnih) sustava. Istraživanje homogene katalize bavi se većinom nasumičnom sintezom peptida i vjerojatnostima nastajanja katalitičkih peptidnih oligomera. Sinteza riboze reakcijom formoze katalizirana je ionom $\mathrm{B}(\mathrm{OH})_{4}{ }^{-}$, koji se može osloboditi trošenjem boratnih minerala. Površine oksidnih minerala i minerala gline daju katalitička mjesta za sintezu oligopeptida i oligonukleotida. Kemoautotrofna teorija ili teorija željezno-sumpornog svijeta pretpostavlja da su se prvi (pionirski) organizmi razvili katalitičkim procesima na česticama (Fe/Ni)S nastalim blizu hidrotermalnih vrela. Rad daje pregled mogućih katalitičkih reakcija na Zemlji prije nastanka života te razmatra selektivnost (regioselektivnost, stereoselektivnost) i geološku raspoloživost katalitičkih minerala uz osvrt na geološke uvjete koji su omogućili katalitičke reakcije na mladoj Zemlji.

\section{Ključne riječi}

Kemoautotrofna teorija, reakcija formoze, postanak života, predbiološka kemija, nasumična sinteza polimera

a Institut za medicinska istraživanja i medicinu rada, Ksaverska c. 2, 10000 Zagreb

b Zavod za geologiju, Prirodoslovno-matematički fakultet, Horvatovac 102a, 10000 Zagreb
Pregledni rad

Prispjelo 20. travnja 2017. Prihvaćeno 24. svibnja 2017.

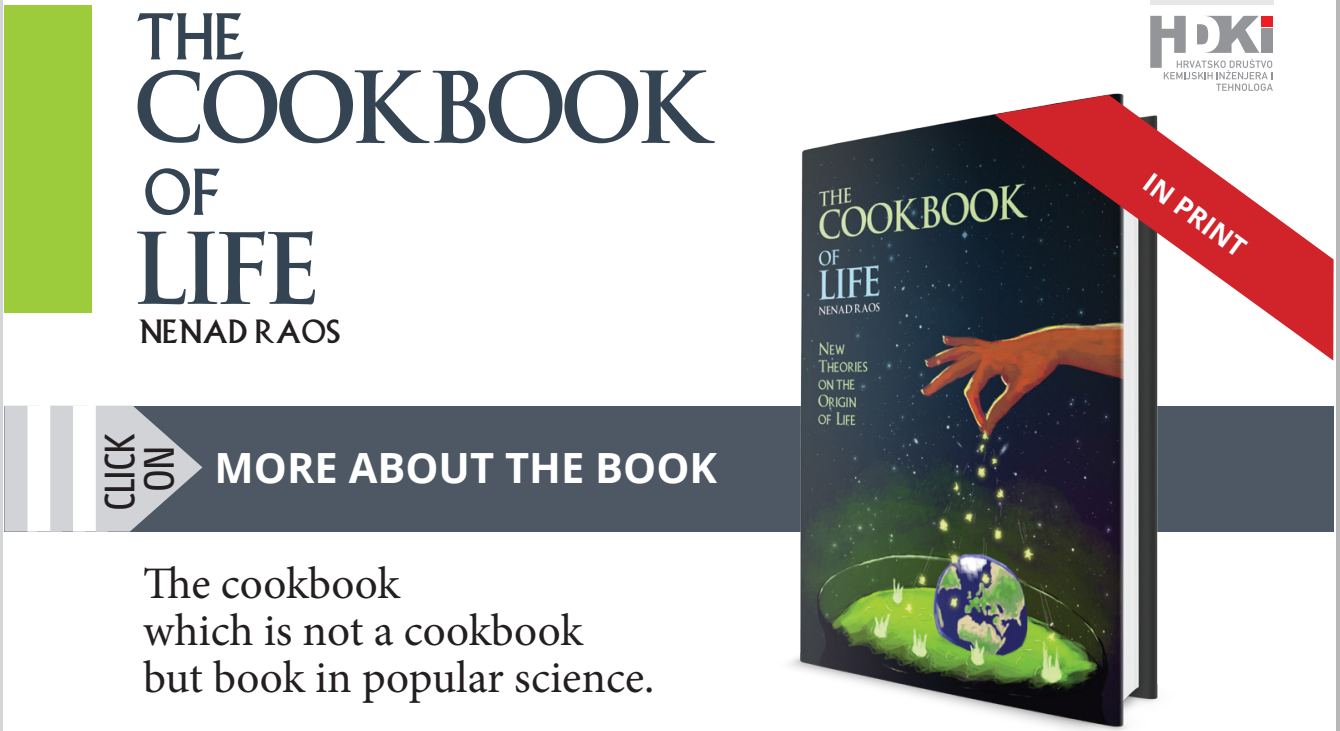

